CATHOLIC SCHOOLS AND BAD BEHAVIOR: A PROPENSITY SCORE MATCHING ANALYSIS

\author{
H. Naci Mocan \\ Erdal Tekin \\ Working Paper 9172 \\ http://www.nber.org/papers/w9172 \\ NATIONAL BUREAU OF ECONOMIC RESEARCH \\ 1050 Massachusetts Avenue \\ Cambridge, MA 02138 \\ September 2002
}

(C) 2002 by H. Naci Mocan and Erdal Tekin. All rights reserved. Short sections of text, not to exceed two paragraphs, may be quoted without explicit permission provided that full credit, including $\odot$ notice, is given to the source. 
Catholic Schools and Bad Behavior: A Propensity Score Matching Analysis

H. Naci Mocan and Erdal Tekin

NBER Working Paper No. 9172

September 2002, Revised March 2007

JEL No. I2,J13

\author{
H. Naci Mocan \\ Department of Economics \\ University of Colorado \\ Campus Box 181; P.O. Box 173364 \\ Denver, CO 80217-3364 \\ and NBER \\ naci.mocan@cudenver.edu \\ Erdal Tekin \\ Department of Economics \\ Andrew Young School of Policy Studies \\ Georgia State University \\ P.O. Box 3992 \\ Atlanta, GA 30302-3992 \\ and NBER \\ tekin@gsu.edu
}

ABSTRACT

Although there is a sizeable literature on the effect of private school attendance on academic student outcomes, the number of studies that investigate the impact of school sector on non-academic outcomes is limited. Using a rich data set, we analyze the impact of Catholic school attendance on the likelihood that teenagers use or sell drugs, commit property crime, have sex, join gangs, attempt suicide, and run away from home. We employ propensity score matching methods to control for the endogeneity of school choice. Catholic school attendance reduces the propensity to use cocaine and to have sex for female students. However, it increases the propensity to use and sell drugs for male students. 


\section{Catholic Schools and Bad Behavior: A Propensity Score Matching Analysis}

\section{Introduction}

The academic performance of K-12 public schools has become a central issue in American politics both at the local and federal level. ${ }^{1}$ One important policy proposal towards improving academic outcomes is to enhance competition between public and private schools through vouchers and other vehicles. ${ }^{2}$ The policy rationale for this "school choice" argument is that vouchers would increase the demand for private schooling, which in turn would put pressure on public schools to improve their quality. Implicit in this proposal is the notion that private schools are more effective in improving student academic outcomes in comparison to public schools. ${ }^{3}$ A large literature has emerged to investigate the validity of this hypothesis (e.g. Altonji, Taber and Elder 2001, Figlio and Stone 2000, Neal 1997, Goldhaber 1996, Evans and Schwab 1995, Sander 1996, and Sander and Krautman 1995). This literature analyzes whether students in Catholic (and other private) schools perform better on standardized exams, are more

\footnotetext{
${ }^{1}$ The average American student does not perform well on standardized tests in comparison to students from other countries. For example, the U.S. ranks $18^{\text {th }}$ in the world on $8^{\text {th }}$ grade science tests, and it ranks $19^{\text {th }}$ in $8^{\text {th }}$ grade math (U.S. Department of Education 2000). The issue is important because there is evidence linking students' academic performance to their future success in the labor market (Murnane et al. 1995). Furthermore, at the aggregate level, there is evidence indicating that education quality of the labor force has a positive impact on economic growth (Hanushek and Kimko 2000).

${ }^{2}$ In response to a question on vouchers in the third Presidential debate, President George W. Bush stated that "... [federal money] will go to the parent so the student can go to a tutoring program, or another public school, or a private school." A number of voucher programs have been implemented since mid-1990s (Peterson et al. 2001).

${ }^{3}$ Because vouchers are used mostly for religious private schools, a heated public debate has emerged regarding the constitutionality of the voucher programs. More precisely, the issue of whether public money can be used to enroll at sectarian schools and whether this is a violation of the First Amendment's prohibition against the "establishment" of religion has been debated at various state courts as well as the Supreme Court of the United States (Lane 2002, Canedy 2002).
} 
likely to graduate from high school, and/or immediately enroll in college in comparison to students in public schools.

Although there exists evidence regarding the positive impact of Catholic schooling on academic outcomes (e.g. Evans and Schwab 1995, Eide, Goldhaber and Showalter 2004), some papers report mixed results or no impact of Catholic schools (e.g. Neal 1997, Sander 1996). ${ }^{4}$ If private schools generate better academic outcomes than their public counterparts, it is conceivable that they also produce more favorable nonacademic outcomes for their students. That is, if the academic environment of the school has an impact on the non-academic behavior of the student, then it is possible that private schools have a differential impact on student behavior, such as criminal activity. The issue is important because if school type has an influence on non-academic student behavior, it would constitute another dimension of the current school choice debate for two reasons. First, risky behavior of youths such as juvenile crime and teenage sexual activity entails social costs, including the financial burden put on the welfare and criminal justice systems. Second, they have ramifications for the future well-being of the individual involved. For example, Mocan, Billups and Overland (2005) show that current criminal activity makes future criminal activity more likely by increasing criminal human capital and depreciating legal human capital. Bound and Freeman (1992) and Freeman and Rodgers (2000) document a negative relationship between youth criminal record and labor market outcomes. In addition, there is evidence indicating that teenage risky behaviors are complements, which implies that there may be positive spillover effects from curtailing risky activities (Dee 1999).

\footnotetext{
${ }^{4}$ For a summary of issues surrounding school choice, see Hoxby (2003).
} 
Research on the impact of school type on non-academic outcomes, such as risky behavior, is not as extensive even though schools are generally evaluated not only on their effectiveness in academic learning but also on their ability to promote healthy social and psychological development of the youth (Watt 2003). Belfield (2003) finds a strong positive association between Catholic school attendance and community service participation, civic skills, political knowledge and tolerance using data from the National Household Education Survey of 1999. Bettinger and Slonim (2005) investigate the effect of vouchers on students' altruistic behavior, exploiting data from an Ohio school voucher lottery. They find that students attending private schools (all Catholic in their sample), after being randomly assigned to these schools through a lottery, tend to give more to charity in experiments. They also find that this private school treatment effect has no impact on the amount children give to other students.

Angrist et al. (2002) use data from a Columbia voucher lottery to examine the effects on a number of academic and non-academic outcomes three years after the random assignment. They find that students who attend private schools as a result of winning the lottery have higher educational attainment and higher scores on achievement tests. The authors also find some evidence suggesting that voucher winners worked less than the losers and were less likely to marry or cohabit as teenagers. In a follow-up study, Angrist, Bettinger, and Kremer (2005) look at the long-term educational consequences of these vouchers. They find that lottery winners have substantially higher high school graduation rates and test scores than losers seven years after the randomized experiment. 
Watt (2003) finds no evidence to indicate that small and/or private schools are better suited for adolescents' emotional well-being using data from the Add Health, refuting the notion that these schools offer a unique sense of community that is conducive to the emotional adjustment of adolescents. In fact, the findings suggest that attending small and private schools cause higher levels of depression and a greater likelihood of suicide attempts among males and cause higher likelihood of use or threat or use of weapons among both males and females. However, it is not clear whether a causal link between small and private schools and adolescent outcomes is identified because of standard endogeneity problems.

Using data from Great Britain, Thornton (1998) suggests that one in ten students in private schools use drugs, and many independent schools are unaware of the extent of drug and alcohol abuse among their students. Figlio and Ludwig (1999) examine the effects of private religious schooling on adolescent non-market behaviors using data from the National Education Longitudinal Survey of 1988. They use instrumental variables to account for unobserved heterogeneity, and find that private religious schools reduce adolescent sexual activity, arrests, and the use of cocaine. They find no consistent evidence that these schools have any effect on drinking, marijuana use, gang involvement, or smoking. Valois et al. (1997) examine a number of health risk behaviors among public and private high school students in South Carolina. They find that attending a private high school does not necessarily have an impact on adolescent risky behavior. In particular, private high school students, compared to public school students, were more likely to report higher rates of alcohol use, drinking and driving, binge drinking, smoking, marijuana use, and use of alcohol and other drugs before sexual 
intercourse. Along the same lines, Sander $(1998,1999)$ suggests that Catholic schools are not more effective than public schools in reducing marijuana, alcohol abuse, or smoking.

In this paper we employ the National Longitudinal Study of Adolescent Health data set (Add Health) to investigate whether school type has an impact on youth risky behavior, and we analyze the impact of attending a Catholic school on 13 different risky behaviors, ranging from using cocaine use to gang fights. We focus on the Catholic school-public school distinction because the number of students in non-Catholic private schools is not large enough in the data set to conduct a meaningful analysis for this group. However, this is not a major shortcoming because Catholic schools students constitute about 49 percent of all private school enrollment (U.S. Department of Education, 2000). Furthermore, most of the research on the impact of school choice has focused on Catholic school-public school differences.

We control for the endogeneity of school choice by employing propensity score matching estimators. We find that Catholic schooling has the opposite effect on the behavior of male and female students. Catholic schooling has a positive influence on the propensity to use and to sell drugs for male students, but it reduces the extent of cocaine use and sexual activity of female students.

The paper is organized as follows. In Section II we discuss the conceptual issues of risky teenage behavior and selection of school type, and describe the propensity score matching methods. In Section III, we introduce the data set used in the analyses. Section IV discusses the propensity score matching procedure and reports the results. Section V concludes the paper. 


\section{Conceptual Issues and Empirical Specifications}

There exists research to suggest that teens may be poor decision makers. For example, Halpern-Felsher and Cauffman (2000) find that adults consistently outperform teens on measures of decision-making competence regarding the long term benefits and costs of interventions such as cosmetic surgery. On the other hand, some analysts report that youths and adults react similarly regarding the perceived consequences of risky behavior (e.g. Beyth-Marom et al., 1993). Recent research in economics has demonstrated that youths respond to prices and incentives as predicted by economic theory (e.g. Harbaugh, Mocan and Visser 2006, Mocan and Rees 2005, William et al. 2002, Gruber and Zinman 2001, Grossman and Saffer 1987). Even though youths may have different risk-aversion and time discount rates than adults, they are not irrational or emotional decision makers (Gruber 2001). As a result, there is room for public policy to influence their behavior by implementing policies that alter prices and incentives.

Behavioral change may also be accomplished by education if education can alter tastes towards risky behavior, or if education can provide information regarding future costs of risky behavior. ${ }^{5}$ Figlio and Ludwig (1999) list a number of reasons why Catholic schools may be relatively more effective than public schools in this regard. First, religious instruction in Catholic schools may change the preferences of teens for certain activities. Second, Catholic schools may tend to offer more strict discipline than public schools. Third, Catholic schools, given that they can more easily regulate who attends,

\footnotetext{
${ }^{5}$ Tastes can also be influenced by other factors such as peers, culture, and role models. For a discussion of the application of behavioral economics to theoretical models of the risky behavior of teens, see O’Donoghue and Rabin (2001).
} 
may offer a better peer group than public schools on average. ${ }^{6}$ Of course, a counterargument can be made to argue that the strict discipline and related environment of Catholic schools may generate unintended consequences such as rebellion and bad behavior associated with it.

The investigation of the effect of Catholic school attendance on student outcomes (academic as well as non-academic) is complicated by empirical difficulties. It is important to control for family and child heterogeneity that may influence both school choice and risky behavior. For example, if parents who put a high value on education tend to send their children to Catholic schools, and if this unobservable parental attribute has an impact on the outcome of the child, then the correlation between Catholic schooling and student outcomes may be attributable to this unobservable family characteristic. Alternatively, negative selection into Catholic schooling may exist. That is, children with higher unobserved probability of undertaking risky activities could be more likely to attend Catholic schools. This is because teens with pre-existing behavioral problems (unobserved to the researchers) may be sent to Catholic schools because their parents may believe that these children are more likely to benefit from the added religious instruction and any extra discipline offered in Catholic schools. Under this scenario, unobserved attributes which make Catholic school choice more likely are positively correlated with the teen's risky behavior, and single equation estimates of the effect of Catholic schooling on risky behavior would be biased toward finding a positive relationship between Catholic schooling and risky behavior.

\footnotetext{
${ }^{6}$ Figlio and Ludwig (1999) list other reasons including an "incapacitation" effect, as students in Catholic schools are assigned more homework and participate in more extracurricular activities. Thus, students in
} 
Our empirical strategy is designed to address these issues. Consider Equation (1)

$$
Y_{i}=\beta_{0}+\beta_{1} D_{i}+X_{i}^{\prime} \beta_{2}+\varepsilon_{i}
$$

where $\mathrm{Y}_{\mathrm{i}}$ is a dichotomous indicator of risky behavior for the student $\mathrm{i}, \mathrm{X}$ is a vector of socio-demographic and other characteristics of the family and the student, and D is an indicator variable for Catholic school attendance.

As discussed above, the propensity to enroll in a Catholic private school $(D=1)$ is likely to be correlated with factors that influence the propensity for risky behavior of the student $(\varepsilon)$. One solution for this endogeneity issue is to find an instrument that explains the tendency for Catholic school attendance, but does not have a direct impact on the teen's propensity to engage in risky behavior. In analyses of the impact of Catholic schooling on academic outcomes, researchers used as instruments the religious beliefs of the student or family (Coleman, Hoffer, Kilgore, 1982; Noell, 1982; Evans and Schwab, 1995, Neal, 1997), measures of the availability of Catholic schooling — the proportion of Catholics in the area, proximity of Catholic schooling, urbanity (Evans and Schwab, 1995; Goldhaber, 1996; Neal, 1997), and interactions between religious beliefs and urbanity (Sander and Krautman, 1995; Sander 1996). In our case, these might not be desirable instruments because religious affiliation, religiosity of the area, and urbanity may also impact the propensity to engage in risky behavior.

To address the potential bias due to unobserved heterogeneity, we use propensity matching estimators, first introduced by Rosenbaum and Rubin (1983). Traditional matching and propensity score matching methods have been increasingly employed in economics (Benjamin 2003, Zhao 2005, Dehejia and Wahba 2002, Heckman, Ichimura,

Catholic schools may have less time available to devote to risky activities. 
and Todd 1997, 1998, Hahn 1998, Lechner 2002, Smith and Todd 2005, Jalan and Ravallion 2003, Mueser, Troske, and Gorislavsky 2005). ${ }^{7}$ In traditional matching estimators, each treatment unit (Catholic school students in our context) is matched to a fixed number of units with the opposite treatment (non-Catholic school students) under the assumptions of unconfoundedness (conditional independence) and common support, which can be formally expressed as

$$
\left(\mathrm{Y}_{\mathrm{i}}=0, \mathrm{Y}_{\mathrm{i}}=1\right) \perp \mathrm{D}_{\mathrm{i}} \mid \mathrm{X}_{\mathrm{i}} \text {, where only } \mathrm{Y}_{\mathrm{i}}=1 \text { or } \mathrm{Y}_{\mathrm{i}}=0 \text { is observed (the student }
$$

engages in risky activity, or does not engage in risky activity); and

$$
0<\operatorname{Pr}\left(\mathrm{D}_{\mathrm{i}}=1 \mid \mathrm{X}_{\mathrm{i}}\right)<1
$$

Unconfoundedness assumption implies that the treatment (Catholic school attendance) is random conditional on some set of observed characteristics $(\mathrm{X})$. This allows for "selection on observables." The common support assumption guarantees that each treated unit (a student in a Catholic school) can be matched with a corresponding control unit (a student attending a public school). The average treatment effect is then calculated as the mean within-match difference in the outcome variable between the treated and untreated units. Unlike regression techniques, matching estimators do not impose any functional form restrictions, nor do they assume a homogenous treatment effect across populations (Zhao 2005).

The application of matching methods becomes impractical and difficult to implement when the set of covariates gets large. For example, in case of $\mathrm{n}$ dichotomous covariates, there are $2^{n}$ possible cells over which the difference in the outcomes for the

\footnotetext{
${ }^{7}$ See also the symposium on matching estimators in the February 2004 issue of the Review of Economics and Statistics.
} 
treatment and controls units needs to be calculated. Obviously, the problem gets worse if some of the covariates are continuous.

One way of dealing with the dimensionality problem is to use a propensity score method, introduced by Rosenbaum and Rubin (1983), who showed that confoundedness and common support assumptions imply

$$
\begin{aligned}
& \left(\mathrm{Y}_{\mathrm{i}}=0, \mathrm{Y}_{\mathrm{i}}=1\right) \perp \mathrm{D}_{\mathrm{i}} \mid p\left(\mathrm{X}_{\mathrm{i}}\right), \quad \text { and } \\
& 0<\operatorname{Pr}\left(\mathrm{D}_{\mathrm{i}}=1 \mid p\left(\mathrm{X}_{\mathrm{i}}\right)\right)<1,
\end{aligned}
$$

where $p\left(\mathrm{X}_{\mathrm{i}}\right)$ is the propensity score, defined as the probability of receiving treatment (attending a Catholic school) conditional on $\mathrm{X}$. Therefore, if $\left(\mathrm{Y}_{\mathrm{i}}=0, \mathrm{Y}_{\mathrm{i}}=1\right)$ and $\mathrm{D}_{\mathrm{i}}$ are independent conditional on $\mathrm{X}_{\mathrm{i}}$, then they are also independent on the propensity score $p\left(\mathrm{X}_{\mathrm{i}}\right)$. This reduces the dimensionality of the matching problem to a single dimension, $p\left(\mathrm{X}_{\mathrm{i}}\right)$. The intuition is that, whereas one conditions on $\mathrm{X}$ in traditional matching estimators, in propensity score matching estimators one conditions on the propensity score, because observations with the same propensity score have the same distribution of the full vector of covariates, X (Dehejia and Wahba 1999).

In practice, the propensity score matching estimator is implemented in two steps. The first step involves estimation of the propensity score using a binary choice model, such as a logistic regression. Rosenbaum and Rubin (1983) defines a propensity score as a function of the vector $\mathrm{X}$, such that $\mathrm{X}_{\mathrm{i}} \perp \mathrm{D}_{\mathrm{i}} \mid p\left(\mathrm{X}_{\mathrm{i}}\right)$, i.e., conditional on the propensity score, the covariates are independent of assignment of treatment. Therefore, for observations with the same propensity score, the distribution of covariates should be the same across the treatment and comparison groups (Dehejia and Wahba 1999). 
The choice of the vector $\mathrm{X}$ and the functional form are determined by whether the estimated propensity score satisfies the Balancing Property Hypothesis, i.e. $\mathrm{X}_{\mathrm{i}} \perp \mathrm{D}_{\mathrm{i}} \mid p\left(\mathrm{X}_{\mathrm{i}}\right)$. To test the Balancing Property Hypothesis, we divide the sample in $k$ equally spaced groups defined over the estimated propensity score and check whether the average propensity score of the treatment and control units differ within each group (Dehejia and Wahba 1999, 2002, Becker and Ichino 2002). If there are significant differences in the average propensity score between treatment and control units in at least one group, we split the group in half and repeat the test. We continue this process until the average propensity score of treatment and control units do not differ in any group. We then test the means of each variable in $\mathrm{X}$ between treatment and control units. If this test fails, we try again with the inclusion of higher order terms and interactions of covariates to the model until this condition is satisfied. Following Becker and Ichino (2002), we restrict this algorithm to only those observations where the propensity score belongs to the intersection of the supports of the propensity score of treatment and control units. Becker and Ichino (2002) suggest that imposing the common support condition this way may improve the quality of the matches used to estimate the average effects of treatment on the treated (ATT).

The second step involves estimating a univariate nonparametric regression to evaluate the average effect of treatment on the treated (ATT), which can be specified as follows

$$
\begin{aligned}
& \mathrm{E}\left(\Delta_{\mathrm{i}} \mid \mathrm{D}_{\mathrm{i}}=1\right)=\mathrm{E}\left\{\left(\mathrm{Y}_{\mathrm{i}}=0, \mathrm{Y}_{\mathrm{i}}=1\right) \mid \mathrm{D}_{\mathrm{i}}=1\right\} \\
& =\mathrm{E}\left\{\mathrm{E}\left\{\left(\mathrm{Y}_{\mathrm{i}}=0, \mathrm{Y}_{\mathrm{i}}=1\right) \mid \mathrm{D}_{\mathrm{i}}=1, p\left(\mathrm{X}_{\mathrm{i}}\right)\right\}\right\} \\
& =\mathrm{E}\left\{\mathrm{E}\left\{\mathrm{Y}_{\mathrm{i}}=1 \mid \mathrm{D}_{\mathrm{i}}=1, p\left(\mathrm{X}_{\mathrm{i}}\right)\right\}-\mathrm{E}\left\{\mathrm{E}\left\{\mathrm{Y}_{\mathrm{i}}=0 \mid \mathrm{D}_{\mathrm{i}}=0, p\left(\mathrm{X}_{\mathrm{i}}\right)\right\} \mid \mathrm{D}_{\mathrm{i}}=1\right\} .\right.
\end{aligned}
$$


Following Dehejia and Wahba (2002) and Leuven and Sianesi (2003), we employ a range of methods to evaluate the ATT. First, we consider nearest neighbor matching without replacement. Rosenbaum (1995) argues that the results can be sensitive to the order in which treatment units and control units are matched. Therefore we consider both "low-to-high" and "high-to-low" matching. In these methods, the treatment units are ranked from lowest to the highest or from highest to lowest propensity score. The highest ranked treatment unit is matched first to a control unit and then that particular comparison unit is removed from further matching (Dehejia and Wahba 2002).

Second, we employ nearest neighbor matching with replacement. Matching with replacement can minimize the propensity score distance between the matched control units and therefore can reduce bias because each treatment unit can be matched to the nearest control unit even if a control unit is used multiple times (Dehejia and Wahba 2002). Third, we use a radius matching estimator with a range of calipers. In radius matching, all control units with the propensity score within a certain radius from the propensity score of the treatment unit are matched.

For each of these methods, we estimate a weighted regression using the control and treatment units where the control units are weighted by the number of times that they are matched to a treatment unit. Estimating a regression can improve the precision of the estimates (Dehejia and Wahba 2002).

It should be noted that the propensity score matching procedure is not a magic bullet. It is reliable to the extent that students' unobservable attributes, which make them more or less likely to attend a Catholic school, do not directly influence their behavior. (An example for such an unobservable is the convenience, such as the distance between 
home and a Catholic school). Standard problems of bias remain if unobservable that influence affect Catholic school attendance also influence the outcome.

\section{Data}

The data used in the paper are drawn from Wave I of the National Longitudinal Study of Adolescent Health (Add Health). ${ }^{8}$ The Add Health is a nationally representative survey of adolescents in grades 7 through 12. It is considered the largest and most comprehensive survey of adolescents ever undertaken in the United States. It was designed to provide detailed information on teen behavior, including their criminal and sexual activities and substance use/abuse. The full sample from Wave I consists of 20,745 adolescents interviewed between April and December 1995. We select a subsample consisting of teens attending a Catholic or public school in an urban area. ${ }^{9}$

The survey contains a section with detailed questions about one's delinquent behavior. Specifically, the respondents were asked whether they had committed any of the following acts in the past 12 months: damaging property, robbery, burglary,

\footnotetext{
${ }^{8}$ The Add Health project is a program project designed by J. Richard Udry (PI) and Peter Bearman, and funded by grant P01-HD31921 from the National Institute of Child Health and Human Development to the Carolina Population Center, University of North Carolina at Chapel Hill, with cooperative funding participation by the National Cancer Institute; the National Institute of Alcohol Abuse and Alcoholism; the National Institute on Deafness and Other Communication Disorders; the National Institute on Drug Abuse; the National Institute of General Medical Sciences; the National Institute of Mental Health; the National Institute of Nursing Research; the Office of AIDS Research, NIH; the Office of Behavior and Social Science Research, NIH; the Office of the Director, NIH; the Office of Research on Women's Health, NIH; the Office of Population Affairs, DHHS; the National Center for Health Statistics, Centers for Disease Control and Prevention, DHHS; the Office of Minority Health, Centers for Disease Control and Prevention, DHHS; the Office of Minority Health, Office of Public Health and Science, DHHS; the Office of the Assistant Secretary for Planning and Evaluation, DHHS; and the National Science Foundation. Persons interested in obtaining data files from The National Longitudinal Study of Adolescent Health should contact Add Health Project, Carolina Population Center, 123 West Franklin Street, Chapel Hill, NC 27516-2524 (email: addhealth@unc.edu).

${ }^{9}$ We exclude teens in rural areas for two reasons: (1) to be consistent with Figlio and Ludwig (1999), and (2) no Catholic school students were observed to be residing outside of an MSA.
} 
participating in a gang fight, running away from home, selling drugs, or stealing something worth more than fifty dollars. Teens also answered questions about whether they had ever used different types of illicit drugs such as marijuana, cocaine, hard drugs (heroin, LSD, ecstasy, mushrooms, etc.), or ever injected illegal drugs with a needle. Finally, they were asked about their sexual behavior and whether they had attempted suicide in the 12 months prior to the interview date.

For sections that involve sensitive information, such as delinquent behavior, the respondent listened to pre-recorded questions through earphones and entered their answers directly on a laptop computer to minimize potential interviewer and parental influences. Turner, et al. (1998) provide evidence that this computer-based method leads to a significantly higher incidence of reported risky activities relative to other survey methods.

When selecting a list of controls variables, it is important to condition only on variables that are strictly exogenous. Any variable that is correlated with both Catholic school attendance and risky behavior may induce bias in the estimates. Keeping this in mind, we include the following variables: binary indicators for age, gender, race and ethnicity of the respondent, whether the parents receive public assistance, mother's education, whether parents are Catholic, marital status of the parents, and whether the school is in an urban location. After selecting teens based on these criteria and excluding cases with missing data, we have a sample of 11,437 adolescents.

The definitions of the variables are provided in Table 1. The upper panel of Table 2 presents the means for the outcome variables for the full sample as well as for students in Catholic and public schools. A star next to the mean value of the variable under the 
public school column indicates that the means are different between Catholic and public schools for that variable. We note that students in Catholic schools are more likely to have engaged in most of the risky behaviors under study. Specifically, Catholic school students are more likely to have used or sold drugs, or committed property damage or burglary. On the other hand, Catholic school students are less likely to have had sex.

The sample characteristics of the explanatory variables are presented in the lower panel of Table 2. There are significant differences between the Catholic school students and the public school students. Catholic school students are more likely to be male, white and non-Hispanic. They are also more likely to have Catholic parents and mothers with higher education. Their parents are also more likely to be married, and less likely to be on welfare in comparison to the parents of public school students.

\section{Results}

\section{Propensity Score Estimation}

Using the algorithm outlined in Section II, we estimate the propensity score for our sample, incorporating the covariates linearly and with some higher-order terms in order to satisfy the balancing property. It has been argued that gender differences in risky behavior can be attributed to differences in risk aversion (Powell and Ansic 1997), discount rates (Lau and Williams 1998), and the motivation for security (Schneider and Lopes 1986). Therefore, we estimate models both for the full sample and for males and females separately. Table App-1 in the Appendix reports the results from the logistic regressions that estimate the propensity scores. As shown in the table, the overwhelming 
majority of covariates are statistically significant determinants of Catholic school attendance, especially for males.

As explained above, the procedure starts by splitting the sample in equally spaced intervals of the propensity score and testing whether the average propensity score of the catholic school attendants and the public school attendants are equal within each interval. If the test fails in one of the intervals, the interval is split in half and the test is repeated. This algorithm generated eight intervals for the whole sample. We also made sure that the balancing property is satisfied for each of the covariates within each interval. In order to improve the quality of matches, we imposed the common support condition in the propensity score estimation. This ensures that each treatment unit has a corresponding matching unit in the comparison group. Because we also estimate models separately for males and females, the above conditions are satisfied for males and females separately. The final number of blocks that satisfies the balancing property is 6 for females and 8 for males. Table 3 displays the distribution of the number of Catholic and public school attendants across blocks within the common support region.

Table 4 reports the results of the balancing property test for the full sample as well as for the male and females samples. T-statistics pertaining to the differences between the covariates of the treatment and control groups are listed in each cell. As shown in Table 4, Catholic school and public school students are identical in their observed characteristics within each block in overwhelming majority of the cases. For example, in the full sample, the differences in the means of the covariates between Catholic and public students are statistically significant at the 5 percent level for only 10 cases out of 154 combinations. The quality of the balances is also very good for the male 
and female samples. In only seven out of 123 cases for males, and five out of 97 cases for females, are the covariates statistically significant between the Catholic school students and public school students.

The mean propensity score is 0.141 with a standard deviation of 0.110 for Catholic school students. Public school students have a mean propensity score of 0.035 with a standard deviation of 0.055 . Among females, the mean and standard deviations of the propensity score are 0.095 and 0.073 for Catholic school students, and 0.029 and 0.041 for public school students. For males, the mean and standard deviation are 0.167 and 0.123 for Catholic school students, and 0.044 and 0.067 for public school students. The fact that the mean estimated propensity scores differ considerably between the treatment and control groups suggests that the two groups are substantially different in a multivariate sense, and it reinforces the desirability of sub-classification (Benjamin 2003).

\section{Estimates of the Catholic School Effect on Risky Behavior}

To put the results into perspective we first estimated linear probability models, where each outcome is a dichotomous indicator of a particular risky behavior. Column 1 of Table 5 reports the estimated coefficients and standard errors of the impact of Catholic school attendance on each risky behavior in linear probability models for the full sample as well as the sample of males and females. Each model contains all variables listed in Table 2. For males, the coefficient of Catholic School is negative in three cases, and positive in 10 . The coefficients are positive and statistically significant in five bad behavior equations. The coefficients are negative in 8 out of 13 cases for 
females, but they are never statistically significant. These results are obtained from regressions which do not control for the endogeneity of school choice; therefore they are not reliable because of the potential bias due to selection into Catholic schooling as described in Section II.

Next, we turn to the propensity score matching estimates that control for selection into the Catholic schooling. Table 5 presents the estimated treatment effects that emerge from various methods described in Section II. The estimates for the full sample are presented in the top panel, and the estimates for the male and female samples are presented in the second and third panels, respectively. In each panel, columns 2 and 3 depict the estimates obtained from matching without replacement. Column 4 displays the estimates from matching with replacement; and columns 5, 6 and 7 present the estimates from radius matching with different calipers. Following Dehejia and Wahba (2002), we include all the controls linearly in the weighted regressions. These variables include the binary variables of male, Hispanic, white, black, Asian, seven age dummies, parental welfare receipt, mother's education dummies, parent's marital status, whether the school is an urban location, and whether the parent is Catholic. $^{10}$

The results are consistent between procedures (columns 2-7). In the full sample, the coefficient of Catholic school is positive and statistically significant for marijuana, injecting drugs, burglary and selling drugs, and negative and significant for having sex, and to some

\footnotetext{
${ }^{10}$ The goal of matching is to choose subsamples of students whose characteristics closely resemble the characteristics of the Catholic school students. In Appendix Table App-2, we present tests for the equality between the means of the covariates for the treatment group (Catholic school students) and the control groups from each matching procedure. As shown in the table, the characteristics of the control samples obtained from each method are very similar. In fact, they are essentially identical for control group characteristics from the matching without replacement method (columns 1 and 2). Contrary to the large mean differences between Catholic school students and public school students in the unmatched (raw) data as shown in Table 2, the two groups closely resemble each other in Appendix Table App-2.
} 
extent for gang fight. However, the middle and bottom panels of the table reveal that there is a substantial difference between males and females regarding the impact of Catholic schooling. Catholic schooling has a negative impact on bad behavior for females, but for males it has a positive impact. For example, for females, Catholic schools tend to reduce the propensity to have sex by 11-13 percentage points and the propensity to use cocaine by 5-6 percentage points. For males, catholic schooling has a positive impact on drug related behavior. Specifically, Catholic schooling increases the propensity to use cocaine by $4-5$ percentage points, to use marijuana by $8-11$ percentage points, to inject drugs by about 2 percentage points, to use hard drugs by $4-5$ percentage points, and to sell drugs by $8-10$ percentage points. In some models, there is a positive impact on the propensity to burglarize (4-5 percentage points) as well. The gender difference in the impact of Catholic schooling on student bad behavior is interesting. To the extent that our estimates are not contaminated by endogeneity of school choice, they suggest that males and females respond differently to the same treatment (being in a Catholic school): while Catholic schooling reduces the propensity of bad behavior of female students, it increases it for male students.

The finding that Catholic schooling decreases the propensity of cocaine use and sexual activity for female students, but increases the propensity to use and sell drugs for male students suggests that boys and girls react differently to the Catholic school environment, which is commonly associated with discipline and structure. This could be because males may have a more difficult time adopting to their environment. It is interesting to note that other research has also identified differential response of males and females to certain "treatments." For example, Sacerdote (2005) shows that among Korean children who are adopted by American families, males complete fewer years of 
schooling, have lower probability of completing four years of college, and they have lower incomes than females. Male adoptees also have higher propensities of drinking and being overweight.

Kling and Liebman (2004), and Kling et al. (2005) analyze data from the Moving To Opportunity program, where families, mostly female-headed minority households with children living in high-poverty public housing projects were offered housing vouchers by lottery. Consistent with our results, these papers find that female and male youth respond differently to this "treatment." The intervention had beneficial effects for females, but adverse effects for males. Specifically, the program reduced the extent of mental health problems and risky behavior for female youth, but it increased injuries and substance use for male youth. The authors conclude that male and female youth appear to respond to their environment in different ways, and provide a number of explanations that may help explain this outcome, ranging from the possibility that males have less effective coping strategies in stressful situations, to differential peer effects.

To demonstrate that our data set is consistent with other databases in one respect, we investigated the impact of Catholic schooling on the Add Health Picture Vocabulary Test (AHPVT). At the beginning of the interview, teens were given the AHPVT, which is a computerized, abridged version of the Peabody Picture Vocabulary Test. The AHPVT involves the interviewer reading a word then the respondent selecting the illustration which best fits the word. We estimated propensity score matching models, separately for females and males, and found a statistically significant impact on Catholic schools on the test scores. For males, the estimate of the impact of Catholic school attendance on AHPVT suggests that all else equal, students in Catholic schools score 
about 0.16 of a standard deviation higher on this standardized exam than students in public schools. For females, the effect is larger. Catholic schooling increases the scores of females students by 0.40 of their standard deviation.

This result is consistent with the ones reported earlier regarding bad behavior. That is, the impact of Catholic schooling is more significant for female students than male students. Catholic schooling reduces the propensity for bad behavior for female students, while it increases it for male students; and the positive impact of Catholic schooling on test scores is greater in magnitude for female students than for male students.

\section{Conclusion}

Engaging in risky behaviors can have negative consequences for the current and future well-being of the individual and his or her family, and these behaviors can also have negative social consequences through their burdens on the welfare and criminal justice systems. Although teenage risky behavior can be changed by sanctions and incentives, another potential tool in this regard is the influence of schooling. In particular, the analysis of the impact of Catholic school education on teenage risky behavior is important because of the current school choice debate in the United Sates.

Using a rich, nationally representative data set, we analyze the impact of Catholic school attendance on risky behaviors such as using or selling drugs, committing theft, robbery and burglary, having sex, engaging in gang-related fights, attempting suicide, and running away from home. We control for the endogeneity of school choice by employing a variety of propensity score methods. We find that for female teenagers Catholic schooling leads to a reduction in the propensity to have sex. For males, on the 
other hand, attending a Catholic school (as opposed to public school) increases the propensity to use and sell drugs. 


\section{Table 1 \\ Variable Definitions}

\begin{tabular}{|c|c|}
\hline \multicolumn{2}{|l|}{ Outcome Variables } \\
\hline Cocaine & $=1$ if ever used cocaine in life, $=0$ otherwise \\
\hline Marijuana & $=1$ if ever used marijuana in life, $=0$ otherwise \\
\hline Hard Drugs & $\begin{array}{l}=1 \text { if ever used ecstasy, mushrooms, speed, ice, heroin, LSD, or } \\
\text { PCP in life, }=0 \text { otherwise }\end{array}$ \\
\hline Injected Drugs & $=1$ if ever injected any illegal drug with a needle, $=0$ otherwise \\
\hline Damaged Property & $\begin{array}{l}=1 \text { if deliberately damaged someone else's property in the past } \\
12 \text { months, }=0 \text { otherwise }\end{array}$ \\
\hline Burglary & $\begin{array}{l}=1 \text { if went into a house or building to steal something in the past } \\
12 \text { months, }=0 \text { otherwise }\end{array}$ \\
\hline Gang Fight & $\begin{array}{l}=1 \text { if took part in a fight where a group of friends was against } \\
\text { another group in the past } 12 \text { months, }=0 \text { otherwise }\end{array}$ \\
\hline Attempted Suicide & $=1$ if attempted suicide in the past 12 months, $=0$ otherwise \\
\hline Had Sex & $=1$ if ever had sexual intercourse,$=0$ otherwise \\
\hline Ran Away from Home & $=1$ if ran away from home in the past 12 months, $=0$ otherwise \\
\hline Sold Drugs & $\begin{array}{l}=1 \text { if sold marijuana or other drugs in the past } 12 \text { months, }=0 \\
\text { otherwise }\end{array}$ \\
\hline Theft & $\begin{array}{l}=1 \text { if stole something worth more than } 50 \text { dollars in the past } 12 \\
\text { months, }=0 \text { otherwise }\end{array}$ \\
\hline Robbery & $\begin{array}{l}=1 \text { if used or threatened to use a weapon to get something from } \\
\text { someone, }=0 \text { otherwise }\end{array}$ \\
\hline \multicolumn{2}{|l|}{ Explanatory Variables } \\
\hline Male & $=1$ if male, $=0$ otherwise \\
\hline Age12- ${ }^{\mathrm{a}}$ & $=1$ if less than or equal to 12 years of age, $=0$ otherwise \\
\hline Age13 & $=1$ if 13 years of age, $=0$ otherwise \\
\hline Age14 & $=1$ if 14 years of age, $=0$ otherwise \\
\hline Age15 & $=1$ if 15 years of age, $=0$ otherwise \\
\hline Age16 & $=1$ if 16 years of age, $=0$ otherwise \\
\hline Age17 & $=1$ if 17 years of age, $=0$ otherwise \\
\hline Age18 & $=1$ if 18 years of age, $=0$ otherwise \\
\hline Age19+ & $=1$ if older than 18 years or age, $=0$ otherwise \\
\hline Hispanic & $=1$ if Hispanic,$=0$ otherwise \\
\hline White & $=1$ if non-Hispanic white, $=0$ otherwise \\
\hline Black & $=1$ if black, $=0$ otherwise \\
\hline Asian & $=1$ if Asian, $=0$ otherwise \\
\hline Other Race ${ }^{\mathrm{a}}$ & $=1$ if other race, $=0$ otherwise \\
\hline Mother $\mathrm{Ed}<\mathrm{HS}^{\mathrm{a}}$ & $=1$ if mother has less than high school degree, $=0$ otherwise \\
\hline Mother Ed=HS & $=1$ if mother has high school degree, $=0$ otherwise \\
\hline Mother Ed $>$ HS & $=1$ if mother has GED, $=0$ otherwise \\
\hline Mother Ed Missing & $=1$ if mother's education is missing, $=0$ otherwise \\
\hline Parent on Welfare & $=1$ if any parent is on welfare, $=0$ otherwise \\
\hline Parent Catholic & $=1$ if respondent's parent is Catholic, $=0$ otherwise \\
\hline Parent Married & $=1$ if lives with a married parent, $=0$ otherwise \\
\hline Urban School & $=1$ if the school is in an urban area, $=0$ otherwise \\
\hline Suburban School ${ }^{\mathrm{a}}$ & $=1$ if the school is in a suburban area, $=0$ otherwise \\
\hline Catholic School & $\begin{array}{l}=1 \text { if attending a Catholic school, }=0 \text { if attending a non-Catholic } \\
\text { public school }\end{array}$ \\
\hline
\end{tabular}


Table 2

Descriptive Statistics

\begin{tabular}{|c|c|c|c|c|c|c|}
\hline \multirow{2}{*}{ Outcome Variable } & \multicolumn{2}{|c|}{ Full Sample } & \multicolumn{2}{|c|}{ Catholic Schools } & \multicolumn{2}{|c|}{ Public Schools } \\
\hline & Mean & $\begin{array}{l}\text { Standard } \\
\text { Deviation }\end{array}$ & Mean & $\begin{array}{l}\text { Standard } \\
\text { Deviation }\end{array}$ & Mean & $\begin{array}{l}\text { Standard } \\
\text { Deviation }\end{array}$ \\
\hline Cocaine & 0.034 & 0.181 & 0.054 & 0.227 & $0.033 * *$ & 0.178 \\
\hline Marijuana & 0.282 & 0.450 & 0.344 & 0.476 & $0.279 * * *$ & 0.449 \\
\hline Hard Drugs & 0.075 & 0.263 & 0.107 & 0.309 & $0.073 * * *$ & 0.261 \\
\hline Injected Drugs & 0.005 & 0.069 & 0.017 & 0.131 & $0.004 * * *$ & 0.065 \\
\hline Damaged Property & 0.182 & 0.386 & 0.227 & 0.419 & $0.180 * *$ & 0.384 \\
\hline Burglary & 0.051 & 0.221 & 0.072 & 0.256 & $0.051 * *$ & 0.219 \\
\hline Gang Fight & 0.209 & 0.407 & 0.183 & 0.387 & 0.210 & 0.407 \\
\hline Attempted Suicide & 0.040 & 0.195 & 0.026 & 0.160 & 0.040 & 0.197 \\
\hline Had Sex & 0.377 & 0.485 & 0.303 & 0.460 & $0.380 * * *$ & 0.485 \\
\hline Ran Away from Home & 0.086 & 0.280 & 0.072 & 0.259 & 0.086 & 0.281 \\
\hline Sold Drugs & 0.075 & 0.263 & 0.142 & 0.349 & $0.072 * * *$ & 0.259 \\
\hline Theft & 0.055 & 0.228 & 0.068 & 0.251 & 0.054 & 0.227 \\
\hline Robbery & 0.041 & 0.198 & 0.050 & 0.218 & 0.040 & 0.197 \\
\hline \multicolumn{7}{|l|}{ Explanatory Variable } \\
\hline Male & 0.495 & $(0.500)$ & 0.608 & $(0.489)$ & $0.490 * * *$ & $(0.500)$ \\
\hline Age12- & 0.033 & $(0.179)$ & 0.013 & $(0.114)$ & $0.034 * *$ & $(0.181)$ \\
\hline Age13 & 0.128 & $(0.335)$ & 0.111 & $(0.315)$ & 0.129 & $(0.335)$ \\
\hline Age14 & 0.153 & $(0.360)$ & 0.142 & $(0.349)$ & 0.154 & $(0.361)$ \\
\hline Age15 & 0.178 & $(0.382)$ & 0.196 & $(0.397)$ & 0.177 & $(0.382)$ \\
\hline Age16 & 0.196 & $(0.397)$ & 0.207 & $(0.406)$ & 0.196 & $(0.397)$ \\
\hline Age17 & 0.182 & $(0.386)$ & 0.198 & $(0.399)$ & 0.182 & $(0.386)$ \\
\hline Age18 & 0.115 & $(0.319)$ & 0.129 & $(0.335)$ & 0.115 & $(0.319)$ \\
\hline Age19+ & 0.013 & $(0.115)$ & 0.004 & $(0.066)$ & $0.014 *$ & $(0.117)$ \\
\hline Hispanic & 0.195 & $(0.396)$ & 0.124 & $(0.330)$ & $0.198 * * *$ & $(0.398)$ \\
\hline White & 0.600 & $(0.490)$ & 0.704 & $(0.457)$ & $0.596 * * *$ & $(0.491)$ \\
\hline Black & 0.242 & $(0.428)$ & 0.135 & $(0.342)$ & $0.246 * * *$ & $(0.431)$ \\
\hline Asian & 0.075 & $(0.263)$ & 0.089 & $(0.286)$ & 0.074 & $(0.262)$ \\
\hline Other race & 0.073 & $(0.261)$ & 0.068 & $(0.251)$ & 0.074 & $(0.261)$ \\
\hline Mother Ed $<$ HS & 0.153 & $(0.360)$ & 0.035 & $(0.184)$ & $0.158 * * *$ & $(0.365)$ \\
\hline Mother Ed=HS & 0.314 & $(0.464)$ & 0.279 & $(0.449)$ & $0.315^{*}$ & $(0.465)$ \\
\hline Mother Ed $>$ HS & 0.442 & $(0.497)$ & 0.623 & $(0.485)$ & $0.434 * * *$ & $(0.496)$ \\
\hline Mother Ed missing & 0.091 & $(0.288)$ & 0.063 & $(0.244)$ & $0.093 * *$ & $(0.290)$ \\
\hline Parent on Welfare & 0.111 & $(0.314)$ & 0.046 & $(0.209)$ & $0.113 * * *$ & $(0.317)$ \\
\hline Parent Catholic & 0.329 & $(0.470)$ & 0.765 & $(0.425)$ & $0.311 * * *$ & $(0.463)$ \\
\hline Parent Married & 0.692 & $(0.462)$ & 0.765 & $(0.425)$ & $0.689 * * *$ & $(0.463)$ \\
\hline Urban school & 0.334 & $(0.472)$ & 0.425 & $(0.495)$ & $0.331 * * *$ & $(0.470)$ \\
\hline Catholic School & 0.040 & $(0.196)$ & & & & \\
\hline Number of Observations & \multicolumn{2}{|c|}{11,437} & \multicolumn{2}{|c|}{459} & \multicolumn{2}{|c|}{10,978} \\
\hline
\end{tabular}

Note: Standard deviations are in parentheses.

$* * *$ Statistically different from Catholic school mean at $\mathrm{p}<0.01$.

** Statistically different from Catholic school mean at $\mathrm{p}<0.05$.

* Statistically different from Catholic school mean at $\mathrm{p}<0.10$. 
Table 3

The Distribution of Catholic and Public School Attendants within Each Block

\begin{tabular}{cccc}
\hline & \multicolumn{2}{c}{ Full Sample } & \\
\cline { 3 - 4 } Blocks & Catholic School & Public School & Total \\
\hline 1 & 33 & 4,363 & 4,396 \\
2 & 51 & 2,690 & 2,741 \\
3 & 57 & 1,686 & 1,743 \\
4 & 70 & 977 & 1,047 \\
5 & 80 & 662 & 742 \\
6 & 112 & 312 & 424 \\
7 & 54 & 77 & 131 \\
8 & 2 & 3 & 5 \\
Total & 459 & 10,770 & 11,229 \\
\hline
\end{tabular}

\section{Male Students}

\begin{tabular}{cccc} 
Blocks & Catholic School & Public School & Total \\
\hline 1 & 11 & 1,737 & 1,748 \\
2 & 31 & 1,350 & 1,381 \\
3 & 33 & 950 & 983 \\
4 & 30 & 497 & 527 \\
5 & 59 & 365 & 424 \\
6 & 78 & 234 & 312 \\
7 & 26 & 39 & 65 \\
8 & 11 & 12 & 23 \\
Total & 279 & 5,184 & 5,463 \\
\hline
\end{tabular}

\begin{tabular}{cccc} 
& \multicolumn{2}{c}{ Female Students } & \\
Blocks & Catholic School & Public School & Total \\
\hline 1 & 41 & 3,346 & 3,387 \\
2 & 25 & 782 & 807 \\
3 & 42 & 633 & 675 \\
4 & 23 & 198 & 221 \\
5 & 32 & 59 & 91 \\
6 & 17 & 72 & 89 \\
Total & 5,090 & 180 & 5,270 \\
\hline
\end{tabular}

Notes: The distributions do not include 208 observations for the full sample, 194 observations for the male sample, and 510 observations for the female sample since these observations are outside the common support region. 
Table 4

T-Statistics for the Equality of the Means of Covariates within

Estimated Propensity Score Blocks

Full Sample

\begin{tabular}{|c|c|c|c|c|c|c|c|c|}
\hline Variable & Block 1 & Block 2 & Block 3 & Block 4 & Block 5 & Block 6 & Block 7 & Block 8 \\
\hline Male & -0.61 & -0.66 & 1.45 & 0.52 & -1.31 & 0.98 & -- & -- \\
\hline Hispanic & $-2.05^{*}$ & 1.24 & -0.54 & 0.25 & 0.54 & -- & -- & -- \\
\hline White & 1.49 & 1.02 & 1.77 & 0.44 & -1.50 & -0.10 & -0.10 & -- \\
\hline Black & 0.86 & -0.68 & -0.80 & 0.82 & 0.59 & 0.40 & -0.58 & -- \\
\hline Asian & -1.62 & -1.77 & -1.12 & -0.52 & 0.71 & 1.71 & 0.84 & -0.77 \\
\hline Age13 & 0.55 & -0.04 & 0.32 & -0.98 & -1.79 & 1.02 & 0.28 & -- \\
\hline Age14 & 0.62 & 0.18 & -1.09 & -1.13 & $-1.94 *$ & 1.32 & 1.20 & 0.77 \\
\hline Age15 & $-2.28 *$ & -0.12 & 0.16 & 1.77 & -0.27 & 0.59 & 0.41 & -0.29 \\
\hline Age16 & 0.03 & 0.32 & 0.55 & -1.07 & 1.20 & -0.10 & -0.69 & 0.77 \\
\hline Age17 & -0.38 & -0.07 & 0.54 & 0.01 & $1.96^{*}$ & -0.97 & 0.08 & -- \\
\hline Age18 & 0.78 & -0.02 & 0.12 & 0.90 & 0.80 & -1.19 & -0.70 & -1.34 \\
\hline Age19 & -0.30 & 0.65 & -0.74 & 0.71 & 0.35 & -- & -- & -- \\
\hline Parent on welfare & 0.64 & 0.15 & -0.36 & 0.24 & -1.23 & 0.54 & 0.84 & -- \\
\hline Mother Ed=HS & 0.06 & $-2.66^{*}$ & 0.49 & $2.28 *$ & -1.14 & -1.85 & 1.25 & -0.77 \\
\hline Mother Ed $>$ HS & $-2.06^{*}$ & -0.14 & 0.50 & -1.08 & 1.20 & 1.41 & -1.76 & 0.77 \\
\hline Mother Ed missing & 0.50 & 0.79 & -1.24 & -0.56 & 0.78 & 0.78 & 0.98 & -- \\
\hline Parent Catholic & 0.16 & 1.25 & -1.90 & -1.67 & -- & -- & -- & -- \\
\hline Urban School & -1.65 & 0.88 & 0.64 & 1.54 & -0.60 & -0.04 & -- & -- \\
\hline Asian*Male & -1.02 & -1.75 & -1.51 & 0.18 & 1.10 & -- & 0.84 & -0.77 \\
\hline $\begin{array}{l}\text { Hispanic*Urban } \\
\text { school }\end{array}$ & $-2.67 *$ & 0.97 & -0.54 & $1.93 *$ & -- & -- & -- & -- \\
\hline $\begin{array}{l}\text { College*Urban } \\
\text { school }\end{array}$ & $-2.34^{*}$ & 1.44 & 0.30 & -0.09 & 0.30 & 1.28 & -1.76 & 0.77 \\
\hline $\begin{array}{l}\text { Asian*Male*Urban } \\
\text { School*Mother } \\
\text { Ed=HS }\end{array}$ & -- & -- & -- & -0.23 & -- & -- & 0.84 & -0.77 \\
\hline Parent Married & 0.22 & 0.80 & 0.03 & -0.49 & 1.30 & -1.12 & -0.57 & -0.77 \\
\hline
\end{tabular}

* Asterisk denotes significance at 5\% level or lower. 
Table 4 (Concluded)

T-Statistics for the Equality of the Means of Covariates within Estimated Propensity Score Blocks

Males

\begin{tabular}{lcccccccc}
\hline Variable & Block 1 & Block 2 & Block 3 & Block 4 & Block 5 & Block 6 & Block 7 & Block 8 \\
\hline Hispanic & -0.78 & -1.61 & 0.004 & -0.29 & 1.01 & -- & - & -- \\
White & 0.26 & 1.49 & 0.67 & 1.86 & -1.00 & -1.20 & -1.39 & 0.06 \\
Black & 1.57 & -0.96 & 0.27 & 1.00 & -1.60 & 1.18 & 0.34 & -- \\
Asian & -1.67 & $-2.50 *$ & -1.35 & -0.69 & $2.02^{*}$ & -0.22 & $2.14^{*}$ & -- \\
Age13 & 0.001 & 0.63 & 0.22 & -0.35 & -1.21 & 1.79 & - & -- \\
Age14 & 0.83 & -0.91 & 0.94 & -0.38 & $-1.93^{*}$ & 1.30 & 1.47 & -- \\
Age15 & -0.46 & -1.04 & 0.90 & -1.07 & 1.13 & -0.62 & -0.22 & 1.42 \\
Age16 & -0.64 & 0.67 & -0.95 & 0.91 & -0.21 & 0.57 & -0.51 & -- \\
Age17 & 0.40 & -0.42 & -0.69 & 0.49 & $2.33 *$ & -0.88 & -1.77 & -0.38 \\
Age18 & 0.16 & 1.06 & -0.02 & 0.43 & -0.74 & -0.82 & 0.52 & -0.68 \\
Age19 & -- & -- & -- & -- & -- & -- & -- & -- \\
Parent on welfare & 0.86 & -1.27 & 0.82 & 0.42 & -1.04 & 1.00 & -- & -- \\
Mother Ed=HS & -0.92 & 0.18 & 1.07 & 1.77 & -0.24 & -1.89 & -- & -- \\
Mother Ed>HS & -0.01 & -1.51 & 0.60 & -0.45 & -0.31 & 1.45 & -- & -- \\
Mother Ed missing & 0.10 & 0.81 & -1.63 & -0.98 & 0.85 & 0.31 & -- & -- \\
Parent Catholic & 0.39 & -0.85 & -0.91 & -0.82 & -0.57 & -- & - & -- \\
Urban School & -0.99 & -0.26 & 0.92 & 1.03 & -1.80 & 0.08 & 1.23 & 0.06 \\
Parent Married & -0.44 & 0.61 & 1.37 & 0.04 & -0.20 & -1.56 & 1.39 & -0.30 \\
Asian*Urban & 0.26 & -0.95 & $-2.43 *$ & -0.16 & 0.70 & -0.22 & $2.14^{*}$ & -- \\
School & & & & & & & & \\
\hline
\end{tabular}

Females

\begin{tabular}{lcccccc}
\hline Variable & Block 1 & Block 2 & Block 3 & Block 4 & Block 5 & Block 6 \\
\hline Hispanic & $-2.24^{*}$ & -1.17 & $2.37^{*}$ & -1.13 & - & -- \\
White & 1.72 & -0.72 & 0.87 & 0.80 & -0.72 & -1.08 \\
Black & 0.14 & 0.20 & -0.87 & -0.72 & -0.44 & 0.46 \\
Asian & $-2.21^{*}$ & 0.42 & -1.38 & -0.09 & 0.73 & 1.23 \\
Age13 & 1.10 & -1.23 & -1.78 & -0.38 & 1.06 & 0.57 \\
Age14 & -0.54 & 0.86 & -1.30 & -0.87 & 1.51 & 0.09 \\
Age15 & $-2.40^{*}$ & 0.76 & 0.46 & 0.70 & 1.51 & 1.64 \\
Age16 & 0.73 & -0.71 & 0.80 & 0.50 & -1.80 & 0.33 \\
Age17 & 0.36 & -0.06 & 0.86 & 0.59 & -0.64 & 0.85 \\
Age18 & 0.55 & 0.89 & 0.17 & -0.21 & -1.19 & $-2.86^{*}$ \\
Age19 & 0.66 & -1.40 & 0.52 & 0.84 & -0.44 & -- \\
Parent on welfare & 0.43 & 0.51 & -0.94 & 0.56 & -0.44 & - \\
Mother Ed=HS & 1.48 & -0.98 & 1.16 & 0.28 & -0.69 & -1.61 \\
Mother Ed $>$ HS & -1.87 & 0.35 & -0.29 & -0.37 & 0.69 & 1.61 \\
Mother Ed missing & 0.33 & -0.29 & 0.18 & 0.48 & -- & -- \\
Parent Catholic & -1.54 & -0.96 & -- & -- & - & -- \\
Urban School & -0.25 & 1.81 & 0.61 & -0.03 & -0.73 & - \\
Parent Married & -0.73 & -0.34 & 0.97 & 0.01 & -1.21 & -0.29 \\
\hline
\end{tabular}

* Asterisk denotes significance at 5\% level or lower. 
Table 5

Regression-Adjusted Propensity Score Matching Estimates of the Catholic Schooling on Risky Behavior

Full Sample

\begin{tabular}{|c|c|c|c|c|c|c|c|}
\hline \multirow{3}{*}{ Control Sample: } & \multirow{3}{*}{$\begin{array}{c}\text { All Public } \\
\text { School } \\
\text { Students* } \\
1\end{array}$} & \multicolumn{2}{|c|}{ Without Replacement } & \multirow{2}{*}{$\begin{array}{l}\text { With Replacement } \\
\text { Nearest Neighbor }\end{array}$} & \multicolumn{3}{|c|}{ Radius Matching } \\
\hline & & Low to High & High to Low & & $\begin{array}{c}\text { Caliper, } \\
\delta=0.00001\end{array}$ & $\begin{array}{c}\text { Caliper, } \\
\delta=0.00005\end{array}$ & $\begin{array}{c}\text { Caliper, } \\
\delta=0.0001\end{array}$ \\
\hline & & 2 & 3 & 4 & 5 & 6 & 7 \\
\hline \multirow[t]{2}{*}{ Cocaine } & $0.020^{*}$ & 0.013 & 0.011 & 0.012 & 0.017 & 0.014 & 0.017 \\
\hline & $(0.011)$ & $(0.014)$ & $(0.014)$ & $(0.016)$ & $(0.014)$ & $(0.013)$ & $(0.014)$ \\
\hline \multirow[t]{2}{*}{ Marijuana } & $0.057 * *$ & $0.073 * * *$ & $0.073 * * *$ & 0.067 & $0.055 * *$ & $0.051 * *$ & $0.053 * *$ \\
\hline & $(0.022)$ & $(0.030)$ & $(0.030)$ & $(0.046)$ & $(0.027)$ & $(0.026)$ & $(0.027)$ \\
\hline \multirow[t]{2}{*}{ Hard Drugs } & $0.025 *$ & 0.011 & 0.010 & $0.038 *$ & 0.009 & 0.007 & 0.011 \\
\hline & $(0.015)$ & $(0.020)$ & $(0.020)$ & $(0.022)$ & $(0.019)$ & $(0.019)$ & $(0.019)$ \\
\hline \multirow[t]{2}{*}{ Injected Drugs } & $0.013 * *$ & $0.013 *$ & $0.013 * *$ & $0.015 * *$ & $0.016 * *$ & $0.015 * *$ & $0.016 * *$ \\
\hline & $(0.006)$ & $(0.007)$ & $(0.007)$ & $(0.007)$ & $(0.008)$ & $(0.007)$ & $(0.007)$ \\
\hline \multirow[t]{2}{*}{ Damaged Property } & 0.016 & -0.019 & -0.021 & 0.005 & -0.018 & -0.025 & -0.023 \\
\hline & $(0.020)$ & $(0.027)$ & $(0.027)$ & $(0.045)$ & $(0.024)$ & $(0.024)$ & $(0.023)$ \\
\hline \multirow[t]{2}{*}{ Burglary } & 0.017 & $0.026 *$ & 0.023 & $0.031 *$ & $0.025 *$ & $0.023 *$ & 0.020 \\
\hline & $(0.013)$ & $(0.015)$ & $(0.015)$ & $(0.018)$ & $(0.014)$ & $(0.014)$ & $(0.013)$ \\
\hline \multirow[t]{2}{*}{ Robbery } & 0.015 & 0.013 & 0.012 & -0.009 & 0.012 & 0.007 & 0.006 \\
\hline & $(0.011)$ & $(0.014)$ & $(0.014)$ & $(0.032)$ & $(0.011)$ & $(0.011)$ & $(0.011)$ \\
\hline \multirow[t]{2}{*}{ Gang Fight } & -0.017 & $-0.046^{*}$ & $-0.054 * *$ & -0.053 & -0.009 & -0.014 & -0.017 \\
\hline & $(0.019)$ & $(0.026)$ & $(0.026)$ & $(0.043)$ & $(0.022)$ & $(0.022)$ & $(0.021)$ \\
\hline \multirow[t]{2}{*}{ Attempted Suicide } & -0.008 & -0.011 & -0.013 & -0.010 & -0.011 & -0.015 & -0.015 \\
\hline & $(0.008)$ & $(0.011)$ & $(0.011)$ & $(0.015)$ & $(0.010)$ & $(0.010)$ & $(0.010)$ \\
\hline \multirow[t]{2}{*}{ Had Sex } & $-0.046 * *$ & $-0.056 *$ & $-0.057 * *$ & $-0.104 * *$ & -0.035 & -0.039 & $-0.044^{*}$ \\
\hline & $(0.021)$ & $(0.030)$ & $(0.029)$ & $(0.052)$ & $(0.026)$ & $(0.025)$ & $(0.024)$ \\
\hline \multirow[t]{2}{*}{ Theft } & 0.007 & 0.006 & 0.009 & 0.022 & 0.018 & 0.013 & 0.010 \\
\hline & $(0.012)$ & $(0.015)$ & $(0.016)$ & $(0.016)$ & $(0.014)$ & $(0.014)$ & $(0.013)$ \\
\hline Run away from & -0.003 & 0.0003 & -0.002 & -0.025 & 0.003 & -0.002 & -0.003 \\
\hline Home & $(0.013)$ & $(0.017)$ & $(0.018)$ & $(0.035)$ & $(0.016)$ & $(0.016)$ & $(0.016)$ \\
\hline \multirow[t]{2}{*}{ Sold Drugs } & $0.066^{* * *}$ & $0.060 * * *$ & $0.055 * * *$ & 0.030 & $0.058 * * *$ & $0.059 * * *$ & $0.060 * * *$ \\
\hline & $(0.016)$ & $(0.021)$ & $(0.020)$ & $(0.034)$ & $(0.020)$ & $(0.020)$ & $(0.019)$ \\
\hline Number of & & & & & & & \\
\hline Observations & 10,948 & 918 & 918 & 716 & 4,215 & 5,380 & 6,666 \\
\hline
\end{tabular}


Table 5 (Continued)

Regression-Adjusted Propensity Score Matching Estimates of the Catholic Schooling on Risky Behavior Males

\begin{tabular}{|c|c|c|c|c|c|c|c|}
\hline \multirow[b]{2}{*}{ Control Sample: } & \multirow[b]{2}{*}{$\begin{array}{l}\text { All Public } \\
\text { School } \\
\text { Students* }\end{array}$} & \multicolumn{2}{|c|}{ Without Replacement } & \multirow{2}{*}{$\begin{array}{l}\text { With Replacement } \\
\text { Nearest Neighbor }\end{array}$} & \multicolumn{3}{|c|}{ Radius Matching } \\
\hline & & Low to High & High to Low & & $\begin{array}{c}\text { Caliper, } \\
\delta=0.00001\end{array}$ & $\begin{array}{c}\text { Caliper, } \\
\delta=0.00005\end{array}$ & $\begin{array}{c}\text { Caliper, } \\
\delta=0.0001\end{array}$ \\
\hline & 1 & 2 & 3 & 4 & 5 & 6 & 7 \\
\hline Cocaine & $\begin{array}{l}0.040 * * \\
(0.017)\end{array}$ & $\begin{array}{c}0.049 * * * \\
(0.018)\end{array}$ & $\begin{array}{l}0.052 * * * \\
(0.018)\end{array}$ & $\begin{array}{l}0.061^{* * *} \\
(0.018)\end{array}$ & $\begin{array}{c}0.044 * * * \\
(0.018)\end{array}$ & $\begin{array}{l}0.043 * * \\
(0.018)\end{array}$ & $\begin{array}{l}0.043 * * \\
(0.019)\end{array}$ \\
\hline Marijuana & $\begin{array}{l}0.086 * * * \\
(0.030)\end{array}$ & $\begin{array}{c}0.109 * * * \\
(0.037)\end{array}$ & $\begin{array}{c}0.110 * * * \\
(0.038)\end{array}$ & $\begin{array}{c}0.099 \\
(0.066)\end{array}$ & $\begin{array}{c}0.082 * * * \\
(0.033)\end{array}$ & $\begin{array}{c}0.089 * * * \\
(0.032)\end{array}$ & $\begin{array}{c}0.098 * * * \\
(0.034)\end{array}$ \\
\hline Hard Drugs & $\begin{array}{l}0.047 * * \\
(0.021)\end{array}$ & $\begin{array}{c}0.038 \\
(0.028)\end{array}$ & $\begin{array}{l}0.043 * \\
(0.026)\end{array}$ & $\begin{array}{c}0.092 * * * \\
(0.027)\end{array}$ & $\begin{array}{l}0.045 * \\
(0.026)\end{array}$ & $\begin{array}{l}0.044 * \\
(0.026)\end{array}$ & $\begin{array}{l}0.039 * \\
(0.024)\end{array}$ \\
\hline Injected Drugs & $\begin{array}{l}0.018 * * \\
(0.009)\end{array}$ & $\begin{array}{c}0.015 \\
(0.010)\end{array}$ & $\begin{array}{c}0.015 \\
(0.010)\end{array}$ & $\begin{array}{l}0.018 * \\
(0.011)\end{array}$ & $\begin{array}{l}0.018 * \\
(0.010)\end{array}$ & $\begin{array}{l}0.018 * \\
(0.009)\end{array}$ & $\begin{array}{l}0.019 * \\
(0.010)\end{array}$ \\
\hline Damaged Property & $\begin{array}{c}0.017 \\
(0.029)\end{array}$ & $\begin{array}{c}0.011 \\
(0.037)\end{array}$ & $\begin{array}{c}0.011 \\
(0.039)\end{array}$ & $\begin{array}{c}0.030 \\
(0.067)\end{array}$ & $\begin{array}{l}-0.032 \\
(0.035)\end{array}$ & $\begin{array}{l}-0.022 \\
(0.035)\end{array}$ & $\begin{array}{l}-0.026 \\
(0.033)\end{array}$ \\
\hline Burglary & $\begin{array}{c}0.027 \\
(0.019)\end{array}$ & $\begin{array}{c}0.031 \\
(0.022)\end{array}$ & $\begin{array}{l}0.035 * \\
(0.021)\end{array}$ & $\begin{array}{l}0.050 * * \\
(0.023)\end{array}$ & $\begin{array}{c}0.025 \\
(0.019)\end{array}$ & $\begin{array}{l}0.035 * \\
(0.021)\end{array}$ & $\begin{array}{c}0.028 \\
(0.020)\end{array}$ \\
\hline Robbery & $\begin{array}{c}0.019 \\
(0.015)\end{array}$ & $\begin{array}{c}0.010 \\
(0.019)\end{array}$ & $\begin{array}{c}0.010 \\
(0.019)\end{array}$ & $\begin{array}{l}-0.019 \\
(0.046)\end{array}$ & $\begin{array}{c}0.017 \\
(0.016)\end{array}$ & $\begin{array}{c}0.014 \\
(0.016)\end{array}$ & $\begin{array}{c}0.012 \\
(0.016)\end{array}$ \\
\hline Gang Fight & $\begin{array}{l}-0.021 \\
(0.026)\end{array}$ & $\begin{array}{l}-0.039 \\
(0.033)\end{array}$ & $\begin{array}{l}-0.043 \\
(0.035)\end{array}$ & $\begin{array}{l}-0.084 \\
(0.061)\end{array}$ & $\begin{array}{l}-0.016 \\
(0.031)\end{array}$ & $\begin{array}{l}-0.014 \\
(0.029)\end{array}$ & $\begin{array}{l}-0.019 \\
(0.029)\end{array}$ \\
\hline Attempted Suicide & $\begin{array}{c}0.002 \\
(0.010)\end{array}$ & $\begin{array}{l}0.0004 \\
(0.012)\end{array}$ & $\begin{array}{c}0.001 \\
(0.013)\end{array}$ & $\begin{array}{l}-0.002 \\
(0.019)\end{array}$ & $\begin{array}{l}-0.008 \\
(0.013)\end{array}$ & $\begin{array}{l}-0.003 \\
(0.014)\end{array}$ & $\begin{array}{l}-0.004 \\
(0.013)\end{array}$ \\
\hline Had Sex & $\begin{array}{l}-0.025 \\
(0.028)\end{array}$ & $\begin{array}{l}-0.041 \\
(0.037)\end{array}$ & $\begin{array}{l}-0.029 \\
(0.035)\end{array}$ & $\begin{array}{l}-0.110 \\
(0.074)\end{array}$ & $\begin{array}{l}-0.030 \\
(0.034)\end{array}$ & $\begin{array}{l}-0.021 \\
(0.031)\end{array}$ & $\begin{array}{l}-0.023 \\
(0.032)\end{array}$ \\
\hline Theft & $\begin{array}{c}0.008 \\
(0.018)\end{array}$ & $\begin{array}{c}0.014 \\
(0.023)\end{array}$ & $\begin{array}{c}0.017 \\
(0.023)\end{array}$ & $\begin{array}{l}0.039 * \\
(0.022)\end{array}$ & $\begin{array}{c}0.021 \\
(0.021)\end{array}$ & $\begin{array}{c}0.024 \\
(0.019)\end{array}$ & $\begin{array}{c}0.016 \\
(0.021)\end{array}$ \\
\hline $\begin{array}{l}\text { Run away from } \\
\text { Home }\end{array}$ & $\begin{array}{l}-0.009 \\
(0.015)\end{array}$ & $\begin{array}{l}-0.011 \\
(0.021)\end{array}$ & $\begin{array}{l}-0.016 \\
(0.021)\end{array}$ & $\begin{array}{l}-0.048 \\
(0.049)\end{array}$ & $\begin{array}{l}-0.011 \\
(0.019)\end{array}$ & $\begin{array}{l}-0.003 \\
(0.017)\end{array}$ & $\begin{array}{l}-0.003 \\
(0.016)\end{array}$ \\
\hline Sold Drugs & $\begin{array}{c}0.095 * * * \\
(0.025)\end{array}$ & $\begin{array}{c}0.097 * * * \\
(0.030)\end{array}$ & $\begin{array}{c}0.103 * * * \\
(0.029)\end{array}$ & $\begin{array}{c}0.075 \\
(0.055)\end{array}$ & $\begin{array}{c}0.085 * * * \\
(0.029)\end{array}$ & $\begin{array}{c}0.085 * * * \\
(0.028)\end{array}$ & $\begin{array}{c}0.082 * * * \\
(0.027)\end{array}$ \\
\hline $\begin{array}{l}\text { Number of } \\
\text { Observations }\end{array}$ & 5,378 & 558 & 558 & 418 & 2,078 & 2,394 & 2,913 \\
\hline
\end{tabular}


Table 5 (Concluded)

Regression-Adjusted Propensity Score Matching Estimates of the Catholic Schooling on Risky Behavior

Females

\begin{tabular}{|c|c|c|c|c|c|c|c|}
\hline \multirow[b]{2}{*}{ Control Sample: } & \multirow[b]{2}{*}{$\begin{array}{l}\text { All Public } \\
\text { School } \\
\text { Students * }\end{array}$} & \multicolumn{2}{|c|}{ Without Replacement } & \multirow{2}{*}{$\frac{\text { With Replacement }}{\text { Nearest Neighbor }}$} & \multicolumn{3}{|c|}{ Radius Matching } \\
\hline & & Low to High & High to Low & & $\begin{array}{c}\text { Caliper, } \\
\delta=\mathbf{0 . 0 0 0 0 1}\end{array}$ & $\begin{array}{c}\text { Caliper, } \\
\delta=0.00005\end{array}$ & $\begin{array}{c}\text { Caliper, } \\
\delta=0.0001\end{array}$ \\
\hline & 1 & 2 & 3 & 4 & 5 & 6 & 7 \\
\hline Cocaine & $\begin{array}{l}-0.005 \\
(0.011)\end{array}$ & $\begin{array}{c}-0.050 * * \\
(0.022)\end{array}$ & $\begin{array}{c}-0.050 * * \\
(0.023)\end{array}$ & $\begin{array}{c}-0.066^{* *} \\
(0.030)\end{array}$ & $\begin{array}{l}-0.022 \\
(0.019)\end{array}$ & $\begin{array}{l}-0.021 \\
(0.020)\end{array}$ & $\begin{array}{l}-0.022 \\
(0.019)\end{array}$ \\
\hline Marijuana & $\begin{array}{c}0.018 \\
(0.033)\end{array}$ & $\begin{array}{l}-0.014 \\
(0.047)\end{array}$ & $\begin{array}{l}-0.022 \\
(0.045)\end{array}$ & $\begin{array}{c}0.005 \\
(0.054)\end{array}$ & $\begin{array}{c}0.011 \\
(0.040)\end{array}$ & $\begin{array}{l}-0.001 \\
(0.040)\end{array}$ & $\begin{array}{c}0.012 \\
(0.040)\end{array}$ \\
\hline Hard Drugs & $\begin{array}{l}-0.003 \\
(0.019)\end{array}$ & $\begin{array}{l}-0.049 \\
(0.030)\end{array}$ & $\begin{array}{l}-0.049 * \\
(0.030)\end{array}$ & $\begin{array}{l}-0.055 \\
(0.037)\end{array}$ & $\begin{array}{l}-0.038 \\
(0.031)\end{array}$ & $\begin{array}{l}-0.040 \\
(0.032)\end{array}$ & $\begin{array}{l}-0.037 \\
(0.029)\end{array}$ \\
\hline Injected Drugs & $\begin{array}{c}0.007 \\
(0.008)\end{array}$ & $\begin{array}{c}0.002 \\
(0.011)\end{array}$ & $\begin{array}{c}0.002 \\
(0.011)\end{array}$ & $\begin{array}{c}0.002 \\
(0.012)\end{array}$ & $\begin{array}{c}0.012 \\
(0.008)\end{array}$ & $\begin{array}{c}0.011 \\
(0.009)\end{array}$ & $\begin{array}{c}0.009 \\
(0.009)\end{array}$ \\
\hline Damaged Property & $\begin{array}{l}-0.012 \\
(0.024)\end{array}$ & $\begin{array}{l}-0.020 \\
(0.033)\end{array}$ & $\begin{array}{l}-0.023 \\
(0.034)\end{array}$ & $\begin{array}{c}0.012 \\
(0.034)\end{array}$ & $\begin{array}{l}-0.010 \\
(0.025)\end{array}$ & $\begin{array}{l}-0.011 \\
(0.026)\end{array}$ & $\begin{array}{l}-0.008 \\
(0.025)\end{array}$ \\
\hline Burglary & $\begin{array}{l}-0.000 \\
(0.014)\end{array}$ & $\begin{array}{l}-0.001 \\
(0.019)\end{array}$ & $\begin{array}{l}-0.001 \\
(0.019)\end{array}$ & $\begin{array}{l}-0.015 \\
(0.027)\end{array}$ & $\begin{array}{c}0.011 \\
(0.015)\end{array}$ & $\begin{array}{c}0.005 \\
(0.015)\end{array}$ & $\begin{array}{c}0.004 \\
(0.016)\end{array}$ \\
\hline Robbery & $\begin{array}{c}0.008 \\
(0.014)\end{array}$ & $\begin{array}{c}0.002 \\
(0.019)\end{array}$ & $\begin{array}{c}0.007 \\
(0.018)\end{array}$ & $\begin{array}{c}0.002 \\
(0.021)\end{array}$ & $\begin{array}{c}0.003 \\
(0.013)\end{array}$ & $\begin{array}{c}0.001 \\
(0.013)\end{array}$ & $\begin{array}{c}0.003 \\
(0.012)\end{array}$ \\
\hline Gang Fight & $\begin{array}{c}-0.014 \\
(0.026)\end{array}$ & $\begin{array}{c}-0.056 \\
(0.037)\end{array}$ & $\begin{array}{l}-0.062 * \\
(0.038)\end{array}$ & $\begin{array}{l}-0.012 \\
(0.037)\end{array}$ & $\begin{array}{l}-0.006 \\
(0.030)\end{array}$ & $\begin{array}{c}-0.005 \\
(0.028)\end{array}$ & $\begin{array}{l}-0.019 \\
(0.029)\end{array}$ \\
\hline Attempted Suicide & $\begin{array}{l}-0.022 \\
(0.014)\end{array}$ & $\begin{array}{l}-0.038 * \\
(0.024)\end{array}$ & $\begin{array}{l}-0.040 \\
(0.025)\end{array}$ & $\begin{array}{l}-0.030 \\
(0.026)\end{array}$ & $\begin{array}{l}-0.021 \\
(0.016)\end{array}$ & $\begin{array}{c}-0.034 * * \\
(0.016)\end{array}$ & $\begin{array}{l}-0.025 \\
(0.016)\end{array}$ \\
\hline Had Sex & $\begin{array}{l}-0.054 \\
(0.033)\end{array}$ & $\begin{array}{c}-0.117 * * * \\
(0.047)\end{array}$ & $\begin{array}{c}-0.118 * * * \\
(0.048)\end{array}$ & $\begin{array}{c}-0.132 * * \\
(0.060)\end{array}$ & $\begin{array}{l}-0.051 \\
(0.040)\end{array}$ & $\begin{array}{l}-0.057 \\
(0.039)\end{array}$ & $\begin{array}{l}-0.058 \\
(0.041)\end{array}$ \\
\hline Theft & $\begin{array}{l}-0.002 \\
(0.014)\end{array}$ & $\begin{array}{c}0.001 \\
(0.019)\end{array}$ & $\begin{array}{c}0.001 \\
(0.020)\end{array}$ & $\begin{array}{l}-0.005 \\
(0.022)\end{array}$ & $\begin{array}{c}0.005 \\
(0.013)\end{array}$ & $\begin{array}{c}0.003 \\
(0.014)\end{array}$ & $\begin{array}{c}0.003 \\
(0.012)\end{array}$ \\
\hline Run away from & 0.007 & 0.012 & 0.006 & 0.007 & 0.011 & 0.004 & 0.010 \\
\hline Home & $(0.023)$ & $(0.032)$ & $(0.030)$ & $(0.037)$ & $(0.028)$ & $(0.030)$ & $(0.030)$ \\
\hline Sold Drugs & $\begin{array}{c}0.023 \\
(0.018)\end{array}$ & $\begin{array}{c}-0.021 \\
(0.028)\end{array}$ & $\begin{array}{l}-0.021 \\
(0.028)\end{array}$ & $\begin{array}{l}-0.034 \\
(0.034)\end{array}$ & $\begin{array}{c}0.013 \\
(0.025)\end{array}$ & $\begin{array}{c}0.004 \\
(0.027)\end{array}$ & $\begin{array}{c}0.005 \\
(0.025)\end{array}$ \\
\hline $\begin{array}{l}\text { Number of } \\
\text { Observations }\end{array}$ & 5,600 & 360 & 360 & 299 & 1,730 & 2,186 & 2,559 \\
\hline
\end{tabular}




\section{References}

Altonji, Joseph, Todd Elder, and Christopher Taber, 2001. "Selection on Observed and Unobserved Variables: Assessing the Effectiveness of Catholic Schools." National Bureau of Economic Research Working Paper 7831, Cambridge, MA.

Angrist, Joshua, Eric Bettinger, Erik Bloom, Elizabeth King, and Michael Kramer, 2002, "Vouchers for Private Schooling in Columbia: Evidence from a Randomized Natural Experiment" American Economic Review, vol. 92, no. 5, December, 1535-1558.

Angrist, Joshua, Eric Bettinger, and Michael Kremer, 2005. "Evidence from a Randomized Experiment: The Effect of Educational Vouchers on Long-run Student Outcomes." Forthcoming American Economic Review.

Becker, Sasha O., and Andrea Ichino, "Estimation of Average Treatment Effects Based on Propensity Scores" The Stata Journal, 2:4, 358-377.

Belfield, Clive R., 2003, "Democratic Education Across School Types: Evidence from the NHES99" Occasional Paper No. 73, National Center for the Study of Privatization in Education Teachers College, Columbia University, May.

Benjamin, Daniel, 2003, "Does 401(k) Eligibility Increase Savings? Evidence from Propensity Score Subclassification” Journal of Public Economics, 87, 1259-1290.

Bettinger, Eric, and Robert Slonim, 2005, “Using Experimental Economics to Measure the Effects of a Natural Educational Experiment on Altruism" NBER Working Paper No. 11725, October.

Beyth-Marom, R., L.Austin, B.Fischhoff, C. Palmgren, and M.J Quadrel, 1993, "Perceived Consequences of Risky Behaviors: Adults and Adolescents." Developmental Psychology 29: 549-63.

Bound, John, and Richard B. Freeman, 1992, "What Went Wrong? The Erosion of Relative Earnings and Employment Among Young Black Men in the 1980s." Quarterly Journal of Economics, 107(1):201-32.

Canedy, Dana, 2002, "Florida Court Bars Use of Vouchers," The New York Times; August 5.

Coleman, James S., Thomas Hoffer, and Sally Kilgore, 1982 High School Achievement: Public, Catholic, and Private Schools Compared. New York: Basic Books.

Dee, Thomas, 1999. "The Complementarity of Teen Smoking and Drinking," Journal of Health Economics 18: 769-93. 
Dehejia, Rajeev H., and Sadek Wahba, 1999, "Causal Effects in Nonexperimental Studies: Reevaluating the Evaluation of Training Programs" Journal of the American Statistical Association 94, December, 1053-1062.

Dehejia, Rajeev H., and Sadek Wahba, 2002, "Propensity Score-Matching Methods for Nonexperimental Causal Studies" Review of Economics and Statistics 84, February, 151175.

Eide, Eric R., Dan D. Goldhaber, and Mark H. Showalter, 2004, "Does Catholic High School Attendance Lead to Attendance at a More Selective College?" Social Science Quarterly, vol. 85, no. 5, December, 1335-1352.

Evans, William and Robert Schwab, 1995. "Finish High School and Starting College: Do Catholic Schools Make a Difference?" Quarterly Journal of Economics 110(4):941-74.

Figlio, David N. and Jens Ludwig 1999, "Sex, Drugs, and Catholic Schools: Private Schooling and Non-Market Adolescent Behaviors," National Bureau of Economic Research Working Paper 7900, Cambridge, MA.

Figlio, David N. and Joe A. Stone, 2000 “Are Private Schools Really Better?" Research in Labor Economics 18: 115-140.

Freeman, Richard B. and William M. Rodgers III, 2000, "Area Economic Conditions and the Labor Market Outcomes of Young Men in the 1990s Expansion," in Prosperity for All? The Economic Boom and African Americans; Robert Cherry and William M. Rodgers (eds.), NY: Russell Sage Foundation.

Goldhaber, Dan, 1996, "Public and Private High Schools: Is School Choice an Answer to the Productivity Problem?" Economics of Education Review 15(2): 93-109.

Grossman, Michael, and Saffer, Henry, 1987, "Drinking Age Laws and Highway Mortality Rates: Cause and Effect" Economic Inquiry, 25(3): 403-418.

Chicago Press; 2001, 69-120.

Gruber, Jonathan, 2001. "Introduction," in Risky Behavior Among Youths, Jonathan Gruber, (ed.) University of Chicago Press, Chicago.

Gruber, Jonathan, and Zinman, Jonathan, 2001. "Youth Smoking in the United States: Evidence and Implications " in Risky Behavior among Youths, Jonathan Gruber (ed.) University of Chicago Press, Chicago.

Hahn, Jinyong, 1998, "On the Role of the Propensity Score in Efficient Semiparametric Estimation of Average Treatment Effects" Econometrica,66, March, 315-331. 
Halpern-Felsher, Bonnie and Elizabeth Cauffman, 2000. "Costs and Benefits of a Decision: Decision-making competence in Adolescents and Adults," University of California San Francisco working paper.

Hanushek, Eric A., and Kimko, Dennis D., 2000, "Schooling Labor-Force Quality, and the Growth of Nations" American Economic Review 90(5): 1184-1208.

Harbaugh, Bill, Naci Mocan and Michael Visser, 2006, "An Experimental Test of Criminal Behavior Among Juveniles and Young Adults," University of Colorado at Denver Working Paper.

Heckman, James, J., Hidehiko Ichimura, and Petra Todd,1997, "Matching as an Econometric Evaluation Estimator: Evidence from Evaluating a Job Training Program" Review of Economic Studies, 64, October, 605-654.

Heckman, James, J., Hidehiko Ichimura, and Petra Todd,1998, "Matching as an Econometric Evaluation Estimator” Review of Economic Studies, 65 (April), 261-294.

Hoxby, Caroline M., 2003, "School Choice and School Competition: Evidence from the United States," 10, pp. 9-65.

Jalan, Jyotsna, and Martin Ravallion, 2003, "Estimating the Benefit Incidence of an Antipoverty Program by Propensity-Score Matching” Journal of Business and Statistics, 21, January, 19-30.

Kling, Jeffrey R, Jeffrey Liebman and Lawrence Katz, 2005, "Experimental Analysis of Neighborhood Effects," Princeton University manuscript.

Kling, Jeffrey R, Jeffrey Liebman, 2004, “Experimental Analysis of Neighborhood Effects on Youth," Princeton University manuscript.

Lane, Charles, 2002; “Court Upholds Ohio School Vouchers; Ruling Says Program Offers Poor Families Freedom of Choice," The Washington Post, June 28.

Lau, Morten I., and Melonie B. Williams. 1998. "Gender-Specific Discount Rates: Evidence from the Experimental Laboratory." paper presented at the 1999 meeting of the American Economic Association.

Lechner, Michael, 2002, "Program Heterogeneity and Propensity Score Matching: An Application to the Evaluation of Active Labor Market Policies" Review of Economics and Statistics, 84, May, 205-220.

Leuven, Edwin, and Barbara Sianesi, 2003. "psmatch2: Stata module to perform full Mahalanobis and propensity score matching, common support graphing, and covariate imbalance testing", http://ideas.repec.org/c/boc/bocode/s432001.html 
Mocan, H. Naci, Billups, Steven C. and Overland, Jody, 2005 "A Dynamic Model of Differential Human Capital and criminal Activity." Economica. 72: 655-81.

Mocan, H. Naci, and Rees, Daniel I, 2005 "Economic Conditions, Deterrence and Juvenile Crime: Evidence from Micro Data." American Law and Economics Review 7(2): 319-49.

Mueser, Peter, R., Kenneth Troske, and Alexey Gorislavsky, 2005, "Using State Administrative Data to Measure Program Performance" Unpublished manuscript.

Murnane, Richard J., John B. Willett, and Frank Levy. 1995. "The Growing Importance of Cognitive Skills in Wage Determination." Review of Economics and Statistics 77(2): 251-66.

Neal, Derek, 1997. "The Effects of Catholic Secondary Schooling on Educational Attainment." Journal of Labor Economics 15():98-123.

Noell, Jay (1982) "Public and Catholic Schools: A Reanalysis of 'Public and Private Schools," Sociology of Education 55:123-132.

O’Donoghue, Ted and Matthew Rabin, 2001. "Risky Behavior Among Youths: Some Issues from Behavioral Economics," in Risky Behavior Among Youths, Jonathan Gruber, ed. University of Chicago Press, Chicago.

Peterson, Paul E., Howell, William G., Wolf, Patrick J., and Campbell, David E., 2001, "School Vouchers: Results from Randomized Experiments." Paper prepared for the Conference on School Choice, sponsored by the National Bureau of Economic Research, Florida Keys, Florida.

Powell, Melanie and David Ansic, 1997, "Gender Differences in Risk Behavior in Financial Decision Making: An Experimental Analysis." Journal of Economic Psychology 18(6): 605-627.

Resnick, Michael D., Bearman, Peter S., etc, 1997, “ Protecting Adolescents From Harm.” Journal of American Medical Association, 278(10):823-832.

Rosenbaum, Paul R. and Donald B. Rubin, 1983. "The Central Role of the Propensity Score in Observational Studies for Causal Effects," Biometrika 70, April, 41-55.

Rosenbaum, Paul R.,1995. Observational Studies, New York: Springer Verlag.

Sacerdote, Bruce, 2005. "How Large are the Treatment Effects from Shifts in Environment? A Study of Korean American Adoptees," Dartmouth College Working Paper. 
Sander, William, 1998, "The Effects of Schooling and Cognitive Ability on Smoking and Marijuana Use by Young Adults” Economics of Education Review 17: 317-324.

Sander, William, 1999, “Cognitive Ability, Schooling and Demand for Alcohol by Young Adults” Education Economics 7:53-66.

Sander, William, 1996. "Catholic Grade Schools and Academic Achievement." Journal of Human Resources 31(3)540-48.

Sander, William and Anthony Krautman, 1995. "Catholic Schools, Dropout Rates, and Educational Attainment.” Economic Inquiry 33(2):217-233.

Schneider, Sandra L. and Lola L. Lopes, 1986, "Reflection in Preferences Under Risk: Who and When May Suggest Why." Journal of Experimental Psychology; Human Perception and Performance, 12(4): 535-548.

Smith, Jeffrey A., and Petra E. Todd, 2005,'Does Matching Overcome LaLonde's Critique of Non-experimental Estimators" Journal of Econometrics, 125, March-April, 305-353.

Thornton, Karen, 1998, "One in 10 private pupils abuses drugs" The Times Educational Supplement, no. 4301, December 4, p. 6.

Turner, Charles F., Leighton Ku, Freya L. Sonenstein, S. M. Rogers, L. D. Lindberg and Joseph H. Pleck, 1998. "Adolescent Sexual Behavior, Drug Use and Violence: New Survey Technology Detects Elevated Prevelance," Science 280(8): 867-873.

United States Department of Education, National Center for Education Statistics; December 2000. "Pursuing Excellence: Comparison of International Eight-Grade Mathematics and Science Achievement from a U.S. Perspective, 1995 and 1999." NCES 2001-028.

Valois, Robert F., Gregory W. Thatcher, Drane J. Wazner, and Belinda M. Reininger, 1997, "Comparison of Selected Health Risk Behaviors Between Adolescents in Public and Private High Schools in South Carolina” Journal of School Health, December, vol. 67 , no. 10 .

Watt, Toni Terling, 2003, “Are Small Schools and Private Schools Better for Adolescents' Emotional Adjustment?" Sociology of Education, vol. 76, October, 344367.

Williams, Jenny, Frank Chaloupka, and Henry Wechsler, 2002, "Are There Differential Effects of Price and Policy on College Students' Drinking Intensity?" NBER Working Paper No: 8702. 
Zhong, Zhao, 2005, "Sensitivity of Propensity Score Methods to the Specifications" Institute for the Study of Labor Discussion Paper No. 1873, December. 


\section{Appendix}

\section{Table App-1}

Estimates of the (Logistic) Propensity Score Model

\begin{tabular}{|c|c|c|c|c|c|c|}
\hline \multirow[b]{2}{*}{ Variable } & \multicolumn{2}{|c|}{ Full Sample } & \multicolumn{2}{|c|}{ Males } & \multicolumn{2}{|c|}{ Females } \\
\hline & Coefficient & $\begin{array}{l}\text { Standard } \\
\text { Error }\end{array}$ & Coefficient & $\begin{array}{l}\text { Standard } \\
\text { Error }\end{array}$ & Coefficient & $\begin{array}{l}\text { Standard } \\
\text { Error }\end{array}$ \\
\hline Male & $0.534 * * *$ & 0.108 & --- & --- & --- & --- \\
\hline Age13 & $0.730^{*}$ & 0.448 & 0.509 & 0.639 & 1.019 & 0.625 \\
\hline Age14 & $0.941 * *$ & 0.443 & 0.880 & 0.632 & $1.096^{*}$ & 0.619 \\
\hline Age15 & $1.123 * * *$ & 0.438 & $1.301 * *$ & 0.620 & 0.865 & 0.620 \\
\hline Age16 & $1.032 * *$ & 0.437 & $1.156^{*}$ & 0.618 & 0.900 & 0.620 \\
\hline Age17 & $1.087 * *$ & 0.438 & $1.365^{* *}$ & 0.618 & 0.686 & 0.627 \\
\hline Age18 & $1.128 * *$ & 0.446 & $1.298 * *$ & 0.631 & 1.035 & 0.631 \\
\hline Hispanic & $-0.631 * * *$ & 0.229 & $-1.886^{* * *}$ & 0.256 & $-1.021 * * *$ & 0.261 \\
\hline White & -0.330 & 0.224 & $-0.701 * *$ & 0.289 & -0.121 & 0.356 \\
\hline Black & $-0.436^{*}$ & 0.266 & $-1.026 * * *$ & 0.352 & 0.127 & 0.412 \\
\hline Asian & -0.353 & 0.332 & $-1.814 * * *$ & 0.408 & 0.192 & 0.431 \\
\hline Mother Ed=HS & $1.389 * * *$ & 0.277 & $1.342 * * *$ & 0.414 & $1.395 * * *$ & 0.370 \\
\hline Mother Ed $>$ HS & $2.367 * * *$ & 0.291 & $2.108 * * *$ & 0.404 & $1.420 * * *$ & 0.365 \\
\hline Mother Ed missing & $1.170 * * *$ & 0.326 & $1.494 * * *$ & 0.454 & 0.491 & 0.517 \\
\hline Parent on Welfare & $-0.587 * * *$ & 0.239 & -0.515 & 0.330 & $-0.596^{*}$ & 0.345 \\
\hline Parent Catholic & $2.403 * * *$ & 0.124 & $2.433 * * *$ & 0.161 & $2.305 * * *$ & 0.195 \\
\hline Parent Married & -0.009 & 0.125 & -0.071 & 0.163 & 0.153 & 0.195 \\
\hline Urban school & $1.727 * * *$ & 0.177 & $0.684 * * *$ & 0.147 & $0.959 * * *$ & 0.196 \\
\hline Asian*Male & $-0.868 * *$ & 0.361 & & & & \\
\hline $\begin{array}{l}\text { Hispanic*Urban } \\
\text { school }\end{array}$ & $-1.574 * * *$ & 0.301 & & & & \\
\hline College*Urban school & $-1.184 * * *$ & 0.216 & & & & \\
\hline Asian*Male*Urban & $-1.302 *$ & 0.770 & & & & \\
\hline School*Mother & & & & & & \\
\hline $\mathrm{Ed}=\mathrm{HS}$ & & & & & & \\
\hline Asian*Urban School & & & $1.016^{*}$ & 0.562 & & \\
\hline Constant & $-7.332 * * *$ & 0.567 & $-6.162 * * *$ & 0.780 & $-7.026^{* * *}$ & 0.797 \\
\hline Log Likelihood & $1,549.4$ & & -878.8 & & -676.6 & \\
\hline Number of & & & & & & \\
\hline Observations & 11,437 & & 5,657 & & 5,780 & \\
\hline
\end{tabular}

$*, * *$, and $* * *$ indicate that the estimates are statistically significant at the $10 \%, 5 \%$, and $1 \%$ levels, respectively. 


\section{Appendix}

Table App-2

T-statistics for the Equality of Covariates between the Treatment Group and Various Control Groups, Full Sample

\begin{tabular}{|c|c|c|c|c|c|c|}
\hline \multirow[b]{2}{*}{ Variable } & \multicolumn{2}{|c|}{ Without Replacement } & \multirow{2}{*}{$\begin{array}{l}\text { With Replacement } \\
\text { Nearest Neighbor }\end{array}$} & \multicolumn{3}{|c|}{ Radius Matching } \\
\hline & Low to High & High to Low & & Caliper, $\delta=0.00001$ & Caliper, $\delta=0.00005$ & Caliper, $\delta=0.0001$ \\
\hline Male & -0.27 & -0.20 & 1.64 & $2.90 *$ & $3.50^{*}$ & $3.81 *$ \\
\hline Hispanic & 0.20 & 0.20 & $-2.67 *$ & $3.62 *$ & 1.26 & -0.19 \\
\hline White & -0.44 & -0.80 & $3.07 *$ & 2.31 & $3.28 *$ & $3.95^{*}$ \\
\hline Black & 0.10 & 0.29 & -1.84 & $-5.16 *$ & $-5.26 *$ & $-5.45 *$ \\
\hline Asian & 0.35 & 0.47 & -1.02 & 1.56 & 0.60 & 0.93 \\
\hline Age13 & 0.00 & 0.00 & -0.69 & 0.92 & 1.09 & 0.56 \\
\hline Age14 & 0.48 & 0.58 & 0.06 & -0.59 & 0.09 & 0.51 \\
\hline Age15 & 0.17 & 0.17 & 0.95 & -0.72 & -0.87 & 0.22 \\
\hline Age16 & -0.08 & -0.08 & 0.65 & -0.84 & -0.85 & -1.06 \\
\hline Age17 & -0.57 & -0.65 & 0.12 & -0.15 & 0.62 & 0.62 \\
\hline Age18 & 0.00 & 0.00 & -1.01 & 2.01 & 0.77 & 0.27 \\
\hline Age19 & 0.58 & 0.58 & 0.09 & -0.49 & -1.13 & -1.55 \\
\hline Parent on welfare & 0.49 & 0.66 & -1.17 & 0.95 & -1.69 & -2.32 \\
\hline Mother $\mathrm{Ed}=\mathrm{HS}$ & -0.15 & -0.22 & -1.46 & 0.62 & -0.09 & -1.14 \\
\hline Mother Ed $>\mathrm{HS}$ & 0.07 & 0.00 & $2.66^{*}$ & -1.34 & 1.83 & $4.08 *$ \\
\hline Mother Ed missing & -0.27 & 0.00 & -1.83 & $3.01 *$ & 0.76 & -0.20 \\
\hline Parent Catholic & 0.31 & 0.31 & $3.64 *$ & $16.09 *$ & $17.52 *$ & $19.02 *$ \\
\hline Urban School & -0.07 & 0.00 & -0.89 & $6.90^{*}$ & $5.01 *$ & $5.12 *$ \\
\hline Parent Married & -0.08 & -0.47 & $2.55^{*}$ & -0.97 & 0.77 & 1.65 \\
\hline
\end{tabular}

*Asterisk denotes significance at the $1 \%$ level. 
Appendix, Table 2 (Continued)

T-statistics for the Equality of Covariates between the Treatment Group and Various Control Groups, Full Sample; Males

\begin{tabular}{|c|c|c|c|c|c|c|}
\hline \multirow[b]{2}{*}{ Variable } & \multicolumn{2}{|c|}{ Without Replacement } & \multirow{2}{*}{$\begin{array}{l}\text { With Replacement } \\
\text { Nearest Neighbor }\end{array}$} & \multicolumn{3}{|c|}{ Radius Matching } \\
\hline & Low to High & High to Low & & Caliper, $\delta=0.00001$ & Caliper, $\delta=0.00005$ & Caliper, $\delta=0.0001$ \\
\hline Hispanic & 0.28 & 0.28 & -2.19 & $2.83 *$ & 1.57 & -0.13 \\
\hline White & -0.69 & -0.29 & $3.05 *$ & 1.37 & 2.00 & $2.93 *$ \\
\hline Black & 0.41 & 0.27 & -1.95 & $-3.40 *$ & $-3.83 *$ & $-4.46 *$ \\
\hline Asian & 0.34 & 0.34 & -0.78 & 1.09 & 0.71 & 0.67 \\
\hline Age13 & 0.15 & -0.15 & -0.72 & 1.08 & 0.38 & -0.37 \\
\hline Age14 & 0.55 & 0.55 & -0.34 & -0.78 & -0.72 & -0.43 \\
\hline Age15 & 0.42 & 0.32 & 1.03 & -1.14 & -0.92 & -0.13 \\
\hline Age16 & -0.40 & -0.30 & 0.74 & -0.99 & -0.64 & 0.03 \\
\hline Age17 & -0.30 & -0.30 & 0.23 & 1.26 & 2.02 & 1.14 \\
\hline Age18 & -0.25 & 0.00 & -1.11 & 1.18 & -0.10 & -0.57 \\
\hline Age19 & -- & -- & -- & -- & -- & -- \\
\hline Parent on welfare & 0.00 & 0.00 & -1.71 & 1.77 & 0.42 & -0.36 \\
\hline Mother Ed=HS & 0.30 & 0.10 & -0.90 & -1.60 & $-2.62 *$ & $-2.94 *$ \\
\hline Mother Ed $>$ HS & -0.18 & -0.09 & $2.47 *$ & 0.21 & 2.20 & $3.52 *$ \\
\hline Mother Ed missing & -0.31 & -0.16 & -2.09 & 2.29 & 1.22 & 0.05 \\
\hline Parent Catholic & 0.20 & 0.20 & $3.38 *$ & $12.84^{*}$ & $13.72 *$ & $15.18^{*}$ \\
\hline Urban School & 0.70 & 0.70 & -0.59 & $5.15^{*}$ & $4.81 *$ & $4.19 *$ \\
\hline Parent Married & -0.20 & -0.30 & $3.12 *$ & -2.22 & -1.44 & -0.25 \\
\hline
\end{tabular}

*Asterisk denotes significance at the $1 \%$ level. 
Appendix, Table 2 (concluded)

T-statistics for the Equality of Covariates between the Treatment Group and Various Control Groups, Full Sample; Females

\begin{tabular}{|c|c|c|c|c|c|c|}
\hline \multirow[b]{2}{*}{ Variable } & \multicolumn{2}{|c|}{ Without Replacement } & \multirow{2}{*}{$\begin{array}{l}\text { With Replacement } \\
\text { Nearest Neighbor }\end{array}$} & \multicolumn{3}{|c|}{ Radius Matching } \\
\hline & Low to High & High to Low & & Caliper, $\delta=0.00001$ & Caliper, $\delta=0.00005$ & Caliper, $\delta=0.0001$ \\
\hline White & -0.44 & -0.22 & 1.27 & -0.26 & 0.47 & 0.89 \\
\hline Asian & 0.68 & 0.33 & 0.20 & 2.34 & 2.33 & 2.21 \\
\hline Age13 & -0.57 & -0.57 & 0.17 & -0.61 & -0.99 & -0.40 \\
\hline Age14 & 0.14 & 0.41 & 0.27 & 0.33 & -0.15 & 0.30 \\
\hline Age15 & 0.42 & 0.42 & 0.60 & -0.33 & -1.03 & -0.62 \\
\hline Age18 & -0.15 & -0.15 & -0.83 & 2.18 & $2.72 *$ & 1.69 \\
\hline Age19 & -0.82 & -0.82 & -1.36 & 1.96 & 0.84 & 0.54 \\
\hline Parent on welfare & 0.48 & 0.48 & -0.41 & 1.86 & 1.47 & 0.44 \\
\hline Mother Ed=HS & 0.56 & 0.56 & 0.25 & 2.02 & 0.31 & 0.02 \\
\hline Mother Ed $>$ HS & -0.75 & -0.75 & 0.25 & $-2.70^{*}$ & -0.33 & 0.49 \\
\hline Mother Ed missing & -0.51 & -0.51 & -1.38 & 1.62 & 0.51 & 0.04 \\
\hline
\end{tabular}

*Asterisk denotes significance at the $1 \%$ level. 